\title{
The Validity of Helcogramma ishigakiensis (Aoyagi, 1954) and a Synopsis of Species of Helcogramma from the Ryukyu Islands, Southern Japan (Perciformes: Tripterygiidae)
}

\author{
Satokuni Tashiro ${ }^{1,3}$ and Hiroyuki Motomura ${ }^{2}$ \\ ${ }^{1}$ Graduate School of Fisheries, Kagoshima University, 4-50-20 Shimoarata, Kagoshima 890-0056, Japan \\ E-mail:k0587888@kadai.jp \\ ${ }^{2}$ The Kagoshima University Museum, 1-21-30 Korimoto, Kagoshima 890-0065, Japan \\ E-mail:motomura@kaum.kagoshima-u.ac.jp \\ ${ }^{3}$ Corresponding author
}

(Received 18 July 2014; Accepted 18 October 2014)

\begin{abstract}
Helcogramma ishigakiensis (Aoyagi, 1954), originally described as Lepidoblennius marmoratus ishigakiensis from the Ryukyu Islands, southern Japan, and subsequently regarded as a junior synonym of Helcogramma inclinata (Fowler, 1946), is redescribed here as a valid species. Helcogramma ishigakiensis is characterized by the following combination of characters: 13-15 (modally 14) second dorsal-fin spines; $28-39$ pored lateral-line scales; $4-5+1+4-6$ (typically $4+1+4$ ) mandibular pores; anterior nostril tentacle unbranched; orbital tentacle simple; nape without scales; and bases of dorsal fins and entire caudal fin reddish in mature male. A synopsis of the other species of Helcogramma occurring in the Ryukyu Islands and a key to the Ryukyu species of the genus are provided.
\end{abstract}

Key Words: Helcogramma aquila, Helcogramma fuscipectoris, Helcogramma inclinata, Helcogramma rhinoceros, Helcogramma striata.

\section{Introduction}

The triplefin genus Helcogramma McCulloch and Waite, 1918 is characterized by having a single lateral line, the first dorsal fin with three spines, the anal fin with a single spine, the pelvic fin with a single spine and two soft rays, and no scales on the head, pectoral-fin base, and ventral surface of the body (Hansen 1986; Fricke 1997; Holleman 2007). Species of Helcogramma are widely distributed in the tropical to temperate waters of the Indo-Pacific Ocean (Hansen 1986; Fricke 1997).

A series of field surveys in the Ryukyu Islands, southern Japan, and our examination of numerous museum specimens collected from these islands has shown the nominal subspecies Lepidoblennius marmoratus ishigakiensis Aoyagi, 1954 to be a valid species, although it had been regarded by Fricke (1997) as a junior synonym of Helcogramma inclinata (Fowler, 1946). It is redescribed here as Helcogramma ishigakiensis. Underwater photographs of males and females taken off Okinawa-jima island are provided. A synopsis of and a key to all species of Helcogramma known from the Ryukyu Islands is also provided, based on our examination of specimens collected from the islands.

\section{Materials and Methods}

Counts and measurements follow Fricke (1997) and Holleman and Bogorodsky (2012), with the mandibular-pore formula following Hansen (1986). Measurements were made to the nearest $0.1 \mathrm{~mm}$ with needle-point calipers under a dissecting microscope. Standard length is abbreviated as SL. Synonymies in the synopsis species of Helcogram$m a$ from the Ryukyu Islands are limited to original descriptions and literature related to the Ryukyu Islands and, in one case, southernmost Kyushu. Curatorial procedures for newly collected specimens followed Motomura and Ishikawa (2013). The specimens examined in this study are deposited in the Academy of Natural Sciences of Drexel University, Philadelphia (ANSP), Bishop Museum, Honolulu (BPBM); Hiwa Museum of Natural History, Shobara (HMNH); Kagoshima University Museum, Kagoshima (KAUM); Kanagawa Prefectural Museum of Natural History, Odawara (KPM); National Museum of Nature and Science, Tsukuba (NSMT); Churashima Research Center, Okinawa Churashima Foundation, Motobu (transferred from University of the Ryukyus: URM); and Yokosuka City Museum, Yokosuka (YCM). Comparative materials examined in this study are as follows-Helcogramma ellioti Herre, 1944: BPBM 27637, 6 males, 4 females, 28.9-39.1 mm SL, Kovalam, Kerala, India, 0-2 m depth, 10 February 1980, J. Randall and W. Smith-Vaniz; BPBM 27684, 4 males, 5 females, 28.0$37.2 \mathrm{~mm}$ SL, Kovalam, Kerala, India, 0-2 m depth, 12 February 1980, J. Randall and W. Smith-Vaniz. Helcogramma habena Williams and McCormick, 1990: USNM 300194 (holotype), male, $34.7 \mathrm{~mm} \mathrm{SL}$, approximately $0.5 \mathrm{~km}$ southeast of Diojo Point, Batan Island, Batanes, Philippines, $20^{\circ} 27^{\prime} 55^{\prime \prime} \mathrm{N}$, $121^{\circ} 57^{\prime} 12^{\prime \prime}$ E, 3-6m depth, G. Johnson and W. Smith-Vaniz. Helcogramma rhinoceros Hansen, 1986: USNM 222370 (ho- 
lotype), male, $27.9 \mathrm{~mm} \mathrm{SL}$, northwest of Putic Island, Palawan Province, Philippines, $10^{\circ} 55^{\prime} \mathrm{N}, 121^{\circ} 02^{\prime} \mathrm{E}, \mathrm{V}$. G. Springer et al., 22 May 1978. Helcogramma striata Hansen, 1986: USNM 221667 (holotype), male, $42.3 \mathrm{~mm}$ SL, Miyake-jima island, Izu Islands, Japan, $34^{\circ} 07^{\prime} \mathrm{N}, 139^{\circ} 30^{\prime} \mathrm{E}, 1-3 \mathrm{~m}$ depth, P. Hadley, 10 December 1977.

Helcogramma ishigakiensis (Aoyagi, 1954)

[Standard Japanese name: Benimon-hebigimpo]

(Figs 1-4, 6D; Tables 1-2)

Lepidoblennius marmoratus ishigakiensis Aoyagi, 1954: 241, 242, fig. 3 (fig. 4 erroneously quoted) (type locality: Ishigaki-jima island, Ryukyu Islands); Matsubara, 1955: 732 (Ishigaki-jima island, Ryukyu Islands).

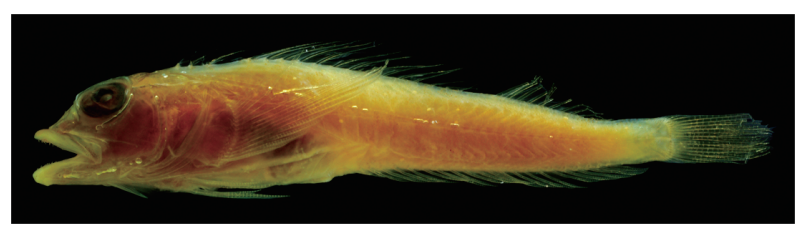

Fig. 1. Photograph of holotype of Lepidoblennius marmoratus ishigakiensis, YCM-P 31283, male, $46.5 \mathrm{~mm} \mathrm{SL}$, Ishigaki-jima island, Ryukyu Islands, Japan.
Helcogramma sp.: Masuda, et al. 1975; 85, 262, fig. F on p. 85 (Ishigaki-jima island, Ryukyu Islands, Japan).

Helcogramma ellioti (not of Herre, 1944): Yoshino, 1984; 281, pl. 264, fig. B (Ishigaki-jima island, Ryukyu Islands).

Helcogramma inclinata (not of Fowler, 1946): Fricke, 1997: 446 (name only).

Holotype. YCM-P 31283, male, $46.5 \mathrm{~mm}$ SL, Ishigakijima island, Ryukyu Islands, Japan, I. Okada and H. Aoyagi, 1938.

Non-type material examined. 41 specimens, 26.1$53.3 \mathrm{~mm}$ SL, all from the Ryukyu Islands. AMAMIOSHIMA ISLAND: KAUM-I. 17519, male, $50.0 \mathrm{~mm}$ SL, KAUM-I. 17520, female, $51.9 \mathrm{~mm} \mathrm{SL}$, tidepool at Tsuchihama, Kasari, $28^{\circ} 24^{\prime} 34^{\prime \prime} \mathrm{N}, 129^{\circ} 40^{\prime} 31^{\prime \prime} \mathrm{E}, 0.5-1 \mathrm{~m}$ depth, M. Meguro and T. Yoshida, 28 March 2009; NSMT-P 75401, male, $29.0 \mathrm{~mm}$ SL, Kaitsu Point, $9 \mathrm{~m}$ depth, S. Yokoyama, 15 November 2006; YCM-P. 34175, male, 36.6 mm SL, YCM-P. 34160, male, $32.9 \mathrm{~mm}$ SL, Hamasaki, Setouchi, Sagami Bay Marine Biological Research Club, 28 August 1994. YORONJIMA ISLAND: KAUM-I. 40381, male, $43.3 \mathrm{~mm}$ SL, off Maehama Beach, $27^{\circ} 01^{\prime} 13^{\prime \prime} \mathrm{N}, 128^{\circ} 24^{\prime} 29^{\prime \prime} \mathrm{E}, 2-10 \mathrm{~m}$ depth, M. Masatoshi and E. Katayama, 17 August 2011; KAUM-I. 45894, male, $33.0 \mathrm{~mm}$ SL, off Maehama Beach, $27^{\circ} 01^{\prime} 13^{\prime \prime} \mathrm{N}$, $128^{\circ} 24^{\prime} 29^{\prime \prime} \mathrm{E}, 2-10 \mathrm{~m}$ depth, KAUM Fish Team, 17 April
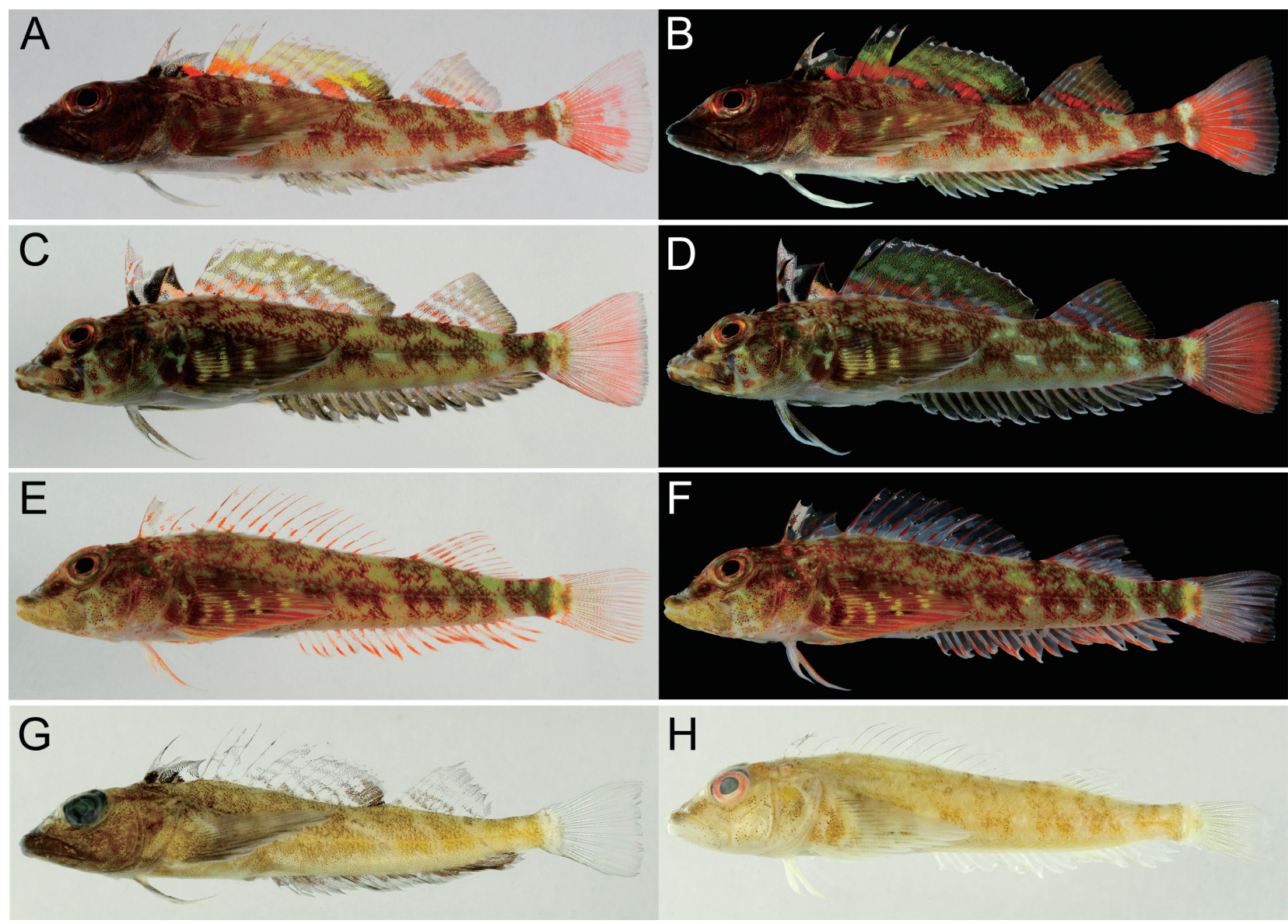

Fig. 2. Color photographs of fresh and preserved specimens of Helcogramma ishigakiensis. A-B, KAUM-I. 40381, male, 43.3 mm SL, Yoron-jima island; C-D, KAUM-I. 17519, male, $50.0 \mathrm{~mm} \mathrm{SL}$, Amami-oshima island; E-F, KAUM-I. 17520, female, $51.9 \mathrm{~mm}$ SL, Amamioshima island; $\mathrm{G}$, preserved specimen, same as $\mathrm{A}-\mathrm{B} ; \mathrm{H}$, preserved specimen, same as $\mathrm{E}-\mathrm{F}$. 

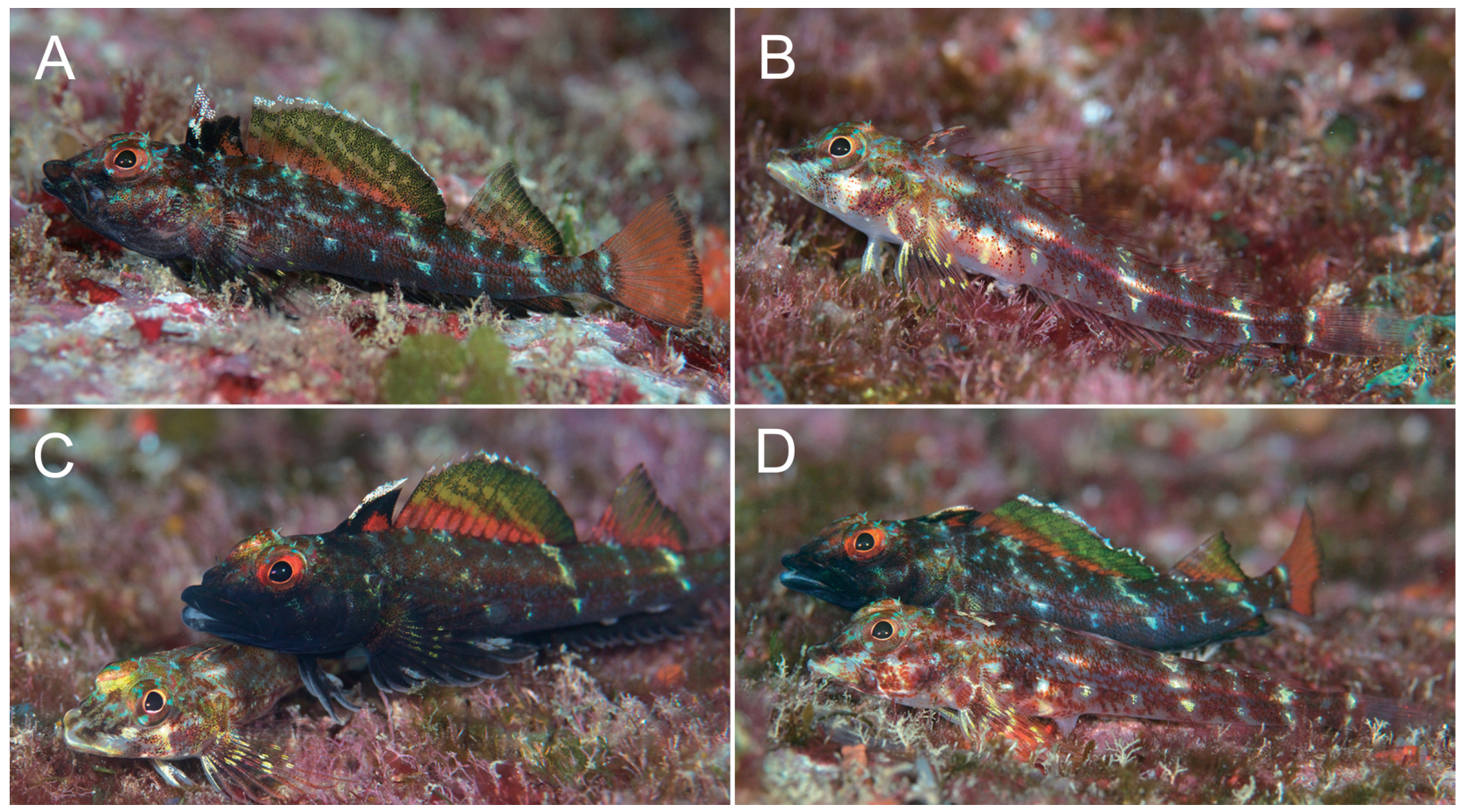

Fig. 3. Underwater photographs of Helcogramma ishigakiensis. A, male; B, female; C, female (left) and male (right); D, female (front) and male (back), north of Ho-Syuu, Onna, Okinawa-jima island, Ryukyu Islands, 3-7 m, 13 (A), 19 (C-D) May 2013. Photos by T. Katano.
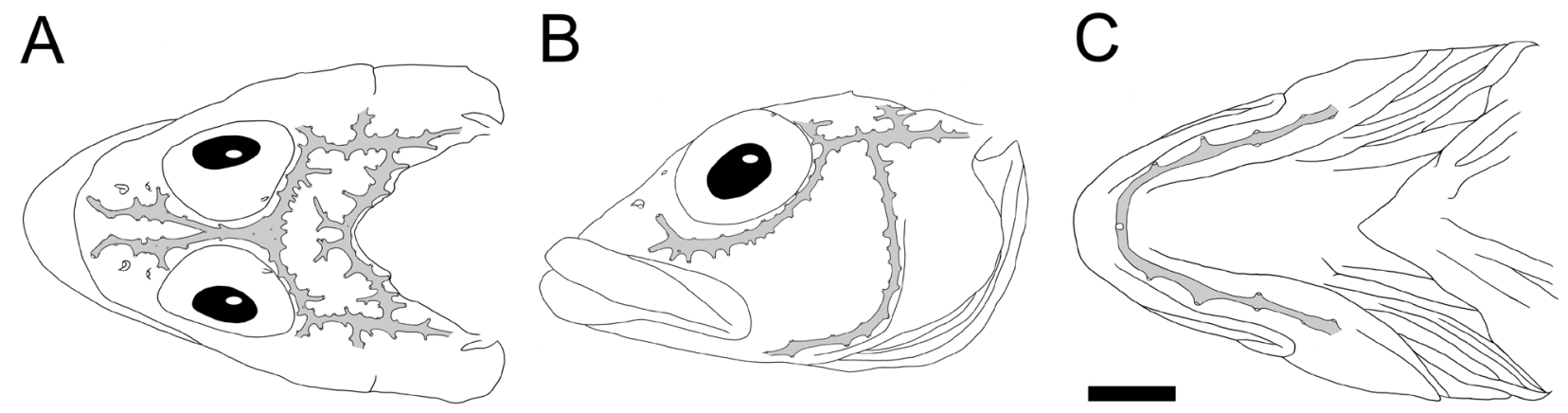

Fig. 4. Cephalic sensory pore system of Helcogramma ishigakiensis, as seen in dorsal (A), lateral (B), and ventral (C) views of head (KAUM-I. 17519, male, $50.0 \mathrm{~mm} \mathrm{SL}$ ). Scale bar $2 \mathrm{~mm}$.

2012; KAUM-I. 47814, male, $49.0 \mathrm{~mm}$ SL, off Maehama Beach, $27^{\circ} 01^{\prime} 13^{\prime \prime} \mathrm{N}, 128^{\circ} 24^{\prime} 29^{\prime \prime} \mathrm{E}, 2-8 \mathrm{~m}$ depth, KAUM Fish Team, 13 August 2012; KAUM-I. 47863, female, $33.2 \mathrm{~mm}$ SL, KAUM-I. 47864, male, 32.7 mm SL, KAUM-I. 47865, male, $32.1 \mathrm{~mm}$ SL, KAUM-I. 47879, female, $29.5 \mathrm{~mm}$ SL, Chabana, $27^{\circ} 03^{\prime} 40^{\prime \prime} \mathrm{N}, 128^{\circ} 25^{\prime} 02^{\prime \prime} \mathrm{E}, 8 \mathrm{~m}$ depth, KAUM Fish Team, 13 August 2012; KAUM-I. 51566, female, $27.6 \mathrm{~mm}$ $\mathrm{SL}$, off Maehama Beach, $27^{\circ} 01^{\prime} 13^{\prime \prime} \mathrm{N}, 128^{\circ} 26^{\prime} 26^{\prime \prime} \mathrm{E}, 2-5 \mathrm{~m}$ depth, KAUM Fish Team, 29 October 2012; KAUM-I. 51335, male, $30.5 \mathrm{~mm}$ SL, off Ritcho, $27^{\circ} 01^{\prime} 20^{\prime \prime} \mathrm{N}$, $128^{\circ} 25^{\prime} 47^{\prime \prime} \mathrm{E}, 10 \mathrm{~m}$ depth, KAUM Fish Team, 24 October 2012. OKINAWA-JIMA ISLAND: HMNH-P 8502, male and female, 43.6-46.0 mm SL, Hentona Beach, Kunigami, 15 December 2004; URM-P 6856, female, $42.0 \mathrm{~mm} \mathrm{SL}$, Minatogawa, $2 \mathrm{~m}$ depth, 30 November 1977; URM-P 6857, male, $46.5 \mathrm{~mm}$ SL, Minatogawa, 14 May 1979; URM-P 6858, female, $40.2 \mathrm{~mm}$ SL, Minatogawa, 24 April 1981; URM-P 6859, female, $44.1 \mathrm{~mm} \mathrm{SL}$, tidepool at Chibishi, 5 May 1981;
URM-P 11273, 2 females, 30.1-42.2 mm SL, Maeda Point, H. Senou and T. Yoshino, 22 July 1985; URM-P 34814, female, $53.3 \mathrm{~mm}$ SL, Minatogawa, H. Yoshigou, 9 December 1995; URM-P 36751, 2 females, 39.1-42.4 mm SL, Sunabe, 27 November. 1996; URM-P 36945, female, $37.5 \mathrm{~mm} \mathrm{SL}$, Minatogawa, 14 December 1996; URM-P 37540, 2 females, 36.3-42.3 mm SL, Akasaki, H. Yoshigou, 27 December 1996; URM-P 37651, male and female, 39.8-50.6 mm SL, Giyan Point, H. Yoshigou et al., 8 February 1997; URM-P 37827 , 3 males, 46.7-47.9 mm SL, URM-P 37829, 2 females, 42.4$50.9 \mathrm{~mm}$ SL, Giizabanda, Asato, Yaese, H. Yoshigou, 10 April 1997. IE-JIMA ISLAND: KPM-NI 8519, male, 27.7 mm SL, 19 September 2001. ISHIGAKI-JIMA ISLAND: NSMT-P 49448, male, $30.8 \mathrm{~mm} \mathrm{SL}$, female, $31.3 \mathrm{~mm} \mathrm{SL}$, off Maesato, $24^{\circ} 19^{\prime} 30^{\prime \prime} \mathrm{N}, 124^{\circ} 11^{\prime} 10^{\prime \prime} \mathrm{E}, 10 \mathrm{~m}$ depth, K. Matsuura et al., 7 December 1995; NSMT-P 49493, male, $26.1 \mathrm{~mm}$ SL, Urazoko Bay, $9 \mathrm{~m}$ depth, K. Matsuura et al., 12 December 1995; URM-P 6855, male, 41.4 mm SL, Oohama, 3 June 1974. 
Table 1. Counts and measurements, expressed as percentages of standard length, of Helcogramma ishigakiensis. Means in parentheses.

\begin{tabular}{|c|c|c|c|}
\hline & \multicolumn{3}{|c|}{ Helcogramma ishigakiensis } \\
\hline & \multirow{2}{*}{$\begin{array}{c}\text { Holotype of Lepidoblennius } \\
\text { marmoratus ishigakiensis }\end{array}$} & \multicolumn{2}{|c|}{ Non-type specimens } \\
\hline & & Males & Females \\
\hline & $n=1$ & $n=22$ & $n=19$ \\
\hline Standard length (mm) & 46.5 & $26.1-50.6$ & $29.5-53.3$ \\
\hline \multicolumn{4}{|l|}{ Counts } \\
\hline Second and third dorsal-fin rays & $\mathrm{XIV}+11$ & $\mathrm{XIII}-\mathrm{XV}+11-12$ & XIII-XV+11-12 \\
\hline Pectoral-fin rays (left side) & $2+7+7=16$ & $1-3+5-8+7=15-16$ & $1-4+5-8+7-8=15-17(16)$ \\
\hline Pectoral-fin rays (right side) & $2+8+7=17$ & $1-4+5-8+7-8=16$ & $1-3+5-8+7-8=12-17(16)$ \\
\hline Anal-fin rays & I, 21 & I, 20-22 (21) & I, 20-22 (21) \\
\hline Pored lateral-line scales (left side) & 35 & $30-39$ & $29-38(33)$ \\
\hline Pored lateral-line scales (right side) & 35 & $28-39$ & 29-37 (33) \\
\hline Total lateral-line scales (left side) & 40 & $40-41$ & $39-41$ \\
\hline Total lateral-line scales (right side) & 39 & $39-41$ & $39-41$ \\
\hline Mandibular pore formula & $4+1+5$ & $4-5+1+4-6(4+1+4)$ & $4-5+1+4(4+1+4)$ \\
\hline Pre-dorsal-fin scales & absent & absent & absent \\
\hline \multicolumn{4}{|l|}{ Measurements (\% of SL) } \\
\hline Body depth & 17.0 & $17.6-19.8(18.6)$ & $16.8-19.8(18.5)$ \\
\hline Body width & 15.9 & $16.3-19.9(18.2)$ & $17.4-20.2(18.8)$ \\
\hline Head length & 31.1 & $30.0-34.5(32.0)$ & $30.1-34.5(31.1)$ \\
\hline Snout length & 10.5 & $9.0-13.3(10.9)$ & $9.6-11.9(11.0)$ \\
\hline Orbit diameter & 9.7 & $8.2-12.2(10.0)$ & $8.4-11.3(9.9)$ \\
\hline Interorbital width & 2.3 & $1.6-2.5(2.0)$ & $1.6-2.5(2.0)$ \\
\hline Upper-jaw length & 15.4 & $14.6-16.4(15.5)$ & $14.7-16.1(15.3)$ \\
\hline Postorbital length & 13.2 & $12.3-14.2(13.3)$ & $12.3-14.0(13.2)$ \\
\hline Pre-1st dorsal-fin length & 24.7 & $23.7-28.5(26.1)$ & $24.3-27.8(26.3)$ \\
\hline Pre-2nd dorsal-fin length & 35.1 & $34.7-38.9(36.5)$ & $34.4-38.0(36.5)$ \\
\hline Pre-3rd dorsal-fin length & 72.5 & $69.1-77.3(72.0)$ & $69.1-74.1(72.0)$ \\
\hline Pre-anal-fin length & 48.7 & $46.2-51.2(48.7)$ & $47.2-52.2(50.1)$ \\
\hline Pre-pectoral-fin length & 31.2 & $29.3-34.2(32.3)$ & $30.1-34.3(32.6)$ \\
\hline Pre-pelvic-fin length & 23.1 & $21.0-25.2(22.6)$ & $21.7-25.5(23.4)$ \\
\hline Caudal-peduncle length & 10.1 & $8.6-12.2(10.1)$ & $9.2-12.8(10.5)$ \\
\hline Caudal-peduncle depth & 7.1 & $6.6-8.2(7.3)$ & $6.3-7.8(7.1)$ \\
\hline 1st spine length of 1 st dorsal fin & damaged & $9.4-13.7(11.5)$ & $8.2-12.5(10.3)$ \\
\hline 2 nd spine length of 1 st dorsal fin & damaged & $6.4-11.9(9.4)$ & $8.1-10.2(9.1)$ \\
\hline $3 \mathrm{rd}$ spine length of 1 st dorsal fin & 8.2 & $6.9-9.8(8.1)$ & $7.0-9.2(7.8)$ \\
\hline Longest spine length of 2 nd dorsal fin & damaged & $13.0-16.1(14.7)$ & $13.2-15.8(14.4)$ \\
\hline Longest ray length of 3rd dorsal fin & damaged & $14.7-17.7(16.1)$ & $13.6-17.8(15.8)$ \\
\hline Pectoral-fin length & 29.6 & $28.6-32.3(29.9)$ & $27.5-32.4(29.9)$ \\
\hline 2 nd ray length of pelvic fin & 20.2 & $19.9-22.9(21.3)$ & $17.8-22.0(20.3)$ \\
\hline
\end{tabular}

Diagnosis. A species of Helcogramma with the following combination of characters: 13-15 (modally 14) second dorsal-fin spines; $28-39$ pored lateral-line scales; $4-5+1+4-6$ (typically $4+1+4$ ) mandibular pores; anterior nostril tentacle unbranched; orbital tentacle simple; nape without scales; basal dorsal fins and caudal fin reddish in mature males.

Description. In following text, data for holotype presented first, followed by other specimen data (if different) in parentheses. Counts and measurements of holotype and other specimens given in Tables 1-2. Cephalic sensory pore systems illustrated in Figs 4A-C, 6D.

Body moderately elongate, slightly laterally compressed anteriorly, progressively more compressed posteriorly. Dorsal profile of snout weakly concave. Anterior nostril located at level of ventral margin of eye, shaped as short, membranous tube with unbranched, thin tentacle. Posterior nostril located at level of middle of eye, its opening elliptical. Eyes oriented dorsolaterally; minute, simple tentacle on posterodorsal part of eye. Interorbital space very narrow, its width less than pupil diameter. Mouth slightly oblique; posterior margin of maxilla extending beyond vertical drawn through middle of pupil. Anterior tip of upper jaw not reaching as high as ventral margin of orbit. Lateral line continuous, with pored scales. Body covered with ctenoid scales; sizes of scales above and below lateral line subequal. No scales on pectoral-fin base, ventral surface of body, or head, including maxilla, interorbital space, preopercle, and opercle. No scales on nape anterior to first spine of first dorsal fin. No scales on fin membranes except for basal part of caudal fin. Origin of 
Table 2. Frequency distribution of selected meristics for species of Helcogramma in the Ryukyu Islands.

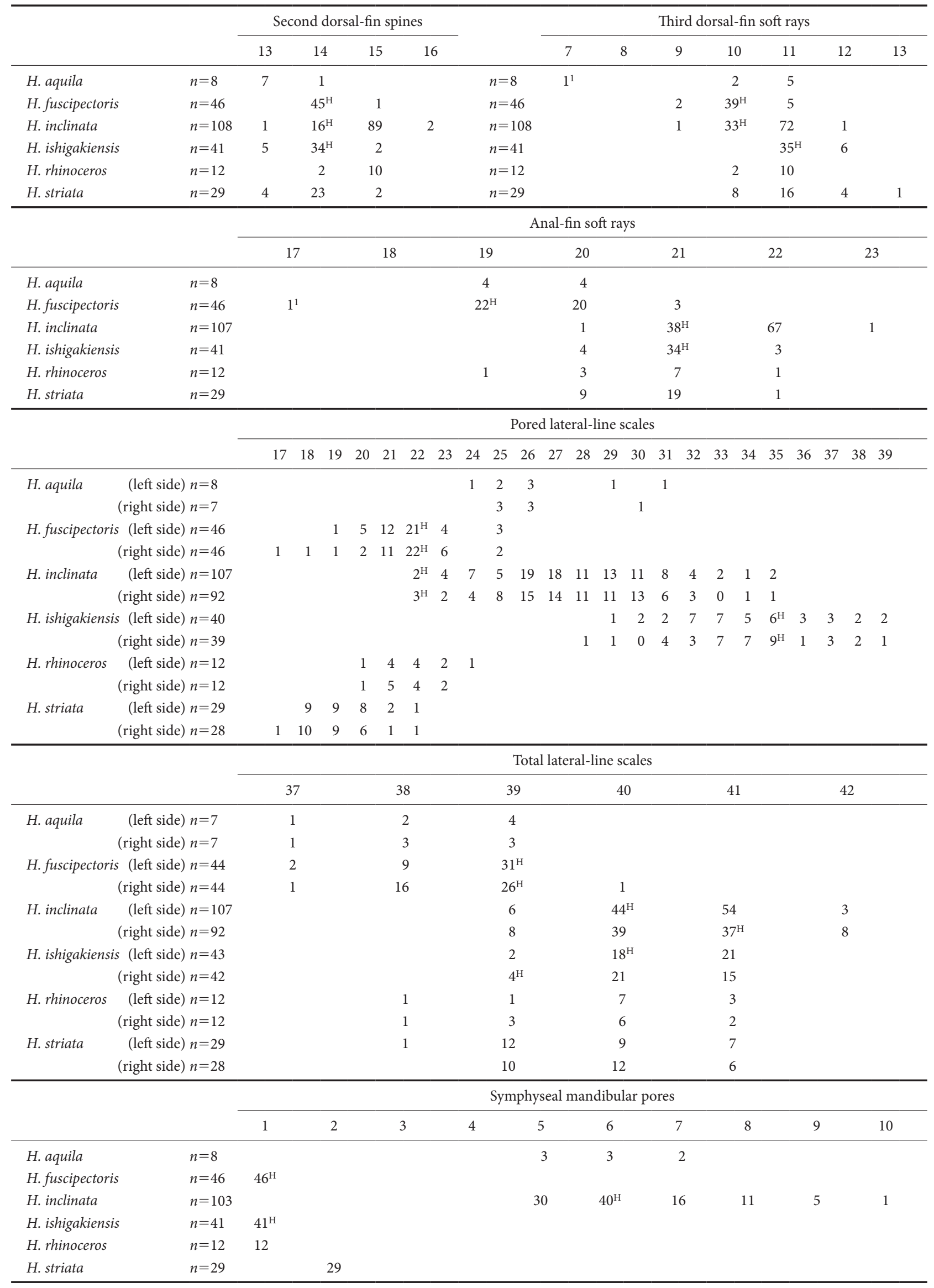


Table 2. Continued.

\begin{tabular}{|c|c|c|c|c|c|c|c|c|c|c|c|c|c|c|c|c|c|c|c|c|c|c|c|c|c|c|}
\hline & & \multicolumn{25}{|c|}{ Total mandibular pores } \\
\hline & & 8 & 9 & 10 & 11 & 12 & 13 & 14 & 15 & 16 & 17 & 18 & 19 & 20 & 21 & 22 & 23 & 24 & 25 & 26 & 27 & 28 & 29 & 30 & 31 & 32 \\
\hline H. aquila & $n=8$ & & & & & & & & & & 2 & 2 & 2 & 1 & & 1 & & & & & & & & & & \\
\hline H. fuscipectoris & $n=46$ & & $46^{\mathrm{H}}$ & & & & & & & & & & & & & & & & & & & & & & & \\
\hline H. inclinata & $n=103$ & & & & & & & & & 1 & 1 & 4 & 9 & $13^{\mathrm{H}}$ & 14 & 16 & 9 & 11 & 9 & 4 & 4 & 3 & 1 & 2 & & 1 \\
\hline H. ishigakiensis & $n=41$ & & 37 & $3^{\mathrm{H}}$ & & 1 & & & & & & & & & & & & & & & & & & & & \\
\hline H. rhinoceros & $n=12$ & & 12 & & & & & & & & & & & & & & & & & & & & & & & \\
\hline H. striata & $n=29$ & 17 & 4 & 8 & & & & & & & & & & & & & & & & & & & & & & \\
\hline
\end{tabular}

${ }^{\mathrm{H}}$ Including data for holotype. ${ }^{1}$ Probable deformity.

first dorsal fin at vertical drawn between preopercular and opercular margins; spines of this fin damaged in holotype (first spine longest, third spine shortest in non-types). Origin of second dorsal fin above fourth (or fifth) pored lateralline scale; spines of this fin also damaged in holotype (second to fourth spine longest, longer than first spine of first dorsal fin). Origin of third dorsal fin above 22nd (22nd to 24 th) pored lateral-line scale; soft rays of this fin damaged in holotype (first or second soft ray longest). Origin of pelvic fin slightly anterior to vertical drawn through base of first dorsal-fin spine. Base of uppermost pectoral-fin ray at level of vertical drawn between third spine of first dorsal fin and first spine of second dorsal fin; pectoral fin pointing posteriorly, with posterior tip of its longest ray at vertical drawn through base of 11th (11th to 13th) spine of second dorsal fin. Origin of anal fin at level of vertical drawn through sixth (sixth or seventh) spine of second dorsal fin. Posterior margin of caudal fin slightly rounded.

Coloration in life of mature males (Fig. 3A, C-D)-Head dark brown to black with irregular bluish stripes and blotches. Body blackish with 6 poorly defined dark brown saddles, and irregular vertical to oblique blue bands between saddles. First dorsal fin black, except for white anterior margin and reddish membrane posterior to third spine. Second dorsal fin mostly green, with white margin and with posteriorly tapering reddish band along base, also with 2 or 3 oblique, pale yellowish-green bands across middle of fin. Third dorsal fin greenish centrally, reddish basally, black marginally. Pectoral fin blackish with 2 to 4 short, irregular, yellowish bands. Anal fin blackish, except for reddish posterior part and white distal margin. Caudal fin red with dusky posterior margin; 2 bright yellowish blotches at base of caudal fin.

Fresh coloration of mature males (based on color photographs of KAUM-I 17519, 40381; Fig. 2A-D)-Similar to coloration in life, but bluish or yellowish stripes, blotches, and saddles significantly faded.

Coloration of preserved male specimens (Figs 1, 2G) Head blackish. Body dusky with 6 distinct saddles (saddles not evident in long-term preserved specimens). First dorsal fin blackish. Second and third dorsal fins semi-transparent with 3 to 4 dark oblique streaks. Pectoral, pelvic, and anal fins blackish. Caudal fin semi-transparent with dusky posterior margin.

Coloration of females in life (Fig. 1B, C-D)-Head and body semi-transparent, mottled with dark red, yellow, and blue streaks, bands, spots, blotches, and saddles. First dorsal fin transparent, with scattered reddish spots and white distal part. Second and third dorsal fins transparent with reddish and whitish rays. Pectoral fin transparent with bright yellow blotches forming 3 or 4 vertical bands; rays reddish. Pelvicfin rays yellowish white. Anal fin transparent with reddish and whitish rays. Caudal fin transparent; rays reddish; 2 bright yellow blotches at base of caudal fin.

Fresh coloration of female (based on color photographs of KAUM-I 17520; Fig. 2E-F)-Head and body pale green with 6 distinct brown saddles; dark brown band extending from anterior part of upper lip to anteroventral margin of orbit. First dorsal fin transparent with scattered reddish spots; upper membrane between first and second spines white; rays reddish. Second and third dorsal fins transparent with scattered white spots; rays reddish. Pectoral-fin membrane transparent, rays reddish, $4-5$ bright yellow blotches or bands on fin. Pelvic fin white, second ray reddish but white distally. Anal-fin membrane transparent; rays reddish but white distally. Caudal-fin membrane transparent; rays reddish; fin base with bright yellow blotch.

Coloration of preserved female specimens (Fig. 2H). Similar to coloration in life, but blue or yellow stripes, blotches, and saddles significantly faded.

Distribution. Known from the Ryukyu Islands, southern Japan; specimens collected from Amami-oshima, Yoron-jima, Okinawa-jima, and Ishigaki-jima islands there. Occurring in rocky reef areas in depths of 3-11 m, and frequently observed adjacent to or sheltering under large rocks.

Remarks. Helcogramma ishigakiensis (Aoyagi, 1954) was originally described as a subspecies, Lepidoblennius marmoratus ishigakiensis. Subsequently, Matsubara (1955) regarded it as a valid species. Lepidoblennius marmoratus is currently regarded as an Australian endemic (Fricke 1994, 1997).

Fricke (1997) regarded Lepidoblennius m. ishigakiensis as a junior synonym of Helcogramma inclinata (Fowler, 1946). However, comparisons of its holotype and a large number of non-type specimens considered herein to be $H$. ishigakiensis with specimens of $H$. inclinata revealed significant differences. Helcogramma ishigakiensis has a single symphyseal mandibular pore ( $v s 5-10$ in $H$. inclinata); no scales on the nape ( $v s$ scales present); no stripe extending from the anterior part of the upper lip to the preopercular margin ( $v s$ a bright blue stripe present); and, in mature males, basally reddish membranes in the anterior part of the first dorsal fin, in the second and third dorsal fins, and in the caudal fin ( $v s$ all fins 
blackish).

Yoshino (1984) reported Helcogramma ellioti from the Ryukyu Islands on the basis of a color photograph of a fresh specimen. This specimen is re-identified herein as Helcogramma ishigakiensis on the basis of its having reddish parts on the dorsal and caudal fins ( $v s$ first dorsal fin and middle of second dorsal fin yellow, and third dorsal and caudal fins pale blue to grey in $H$. ellioti) and no stripe extending from the posterior part of the upper lip to the preopercular margin ( $v s$ a bright blue stripe in $H$. ellioti). That said, $H$. ishigakiensis is likely to be closely related to $H$. ellioti because both have a large number of pored lateral-line scales; however, $H$. ishigakiensis differs in having 20-22 (usually 21) anal-fin soft rays (vs 18-19 in H. ellioti); 1 symphyseal mandibular pore ( $v$ s 3-5); and 39-41 total-lateral line scales [vs 35-38 (modally 36)] [data for $H$. ellioti from Holleman (2007) and this study].

\section{Synopsis of Species of Helcogramma from the Ryukyu Islands}

Helcogramma aquila Williams and McCormick, 1990 [Standard Japanese name: Momiji-hebigimpo] (Figs 5A-B, 6A; Table 2)

Helcogramma aquila Williams and McCormick, 1990: 1021, fig. 3A-B (type locality: Batan Island, Batan Islands, Philippines); Tashiro and Motomura 2013: 10, figs 1-4
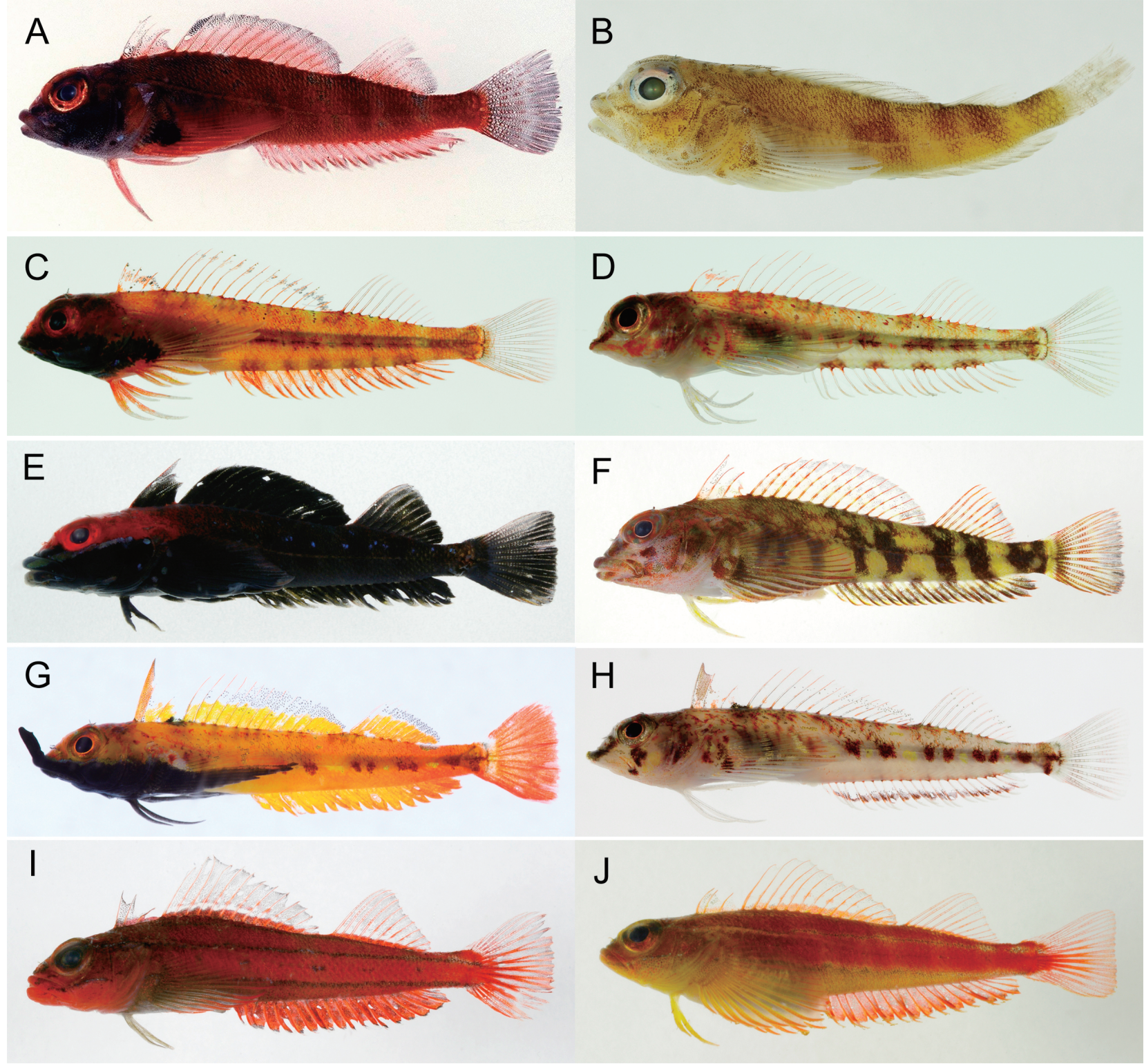

Fig. 5. Color photographs of fresh (A, C-J) and preserved (B) specimens of Helcogramma in the Ryukyu Islands. Helcogramma aquila, A, HMNH-P 9144, male, 35.0 mm SL, B, HMNH-P 4409, female, $32.5 \mathrm{~mm}$ SL; H. fuscipectoris, C, KAUM-I. 63398, male, $22.6 \mathrm{~mm}$ SL, D, KAUM-I. 63399, female, $24.2 \mathrm{~mm}$ SL; H. inclinata, E, KAUM-I. 29669, male, $42.5 \mathrm{~mm}$ SL, F, KAUM-I. 30625, female, $49.2 \mathrm{~mm}$ SL; H. rhinoceros, G, KAUM-I. 51381, male, 27.2 mm SL; H, KAUM-I. 63467, female, 29.4 mm SL; H. striata, I, KAUM-I. 37748, male, 38.5 mm SL, J, KAUM-I. 29515, female, $33.5 \mathrm{~mm}$ SL. 

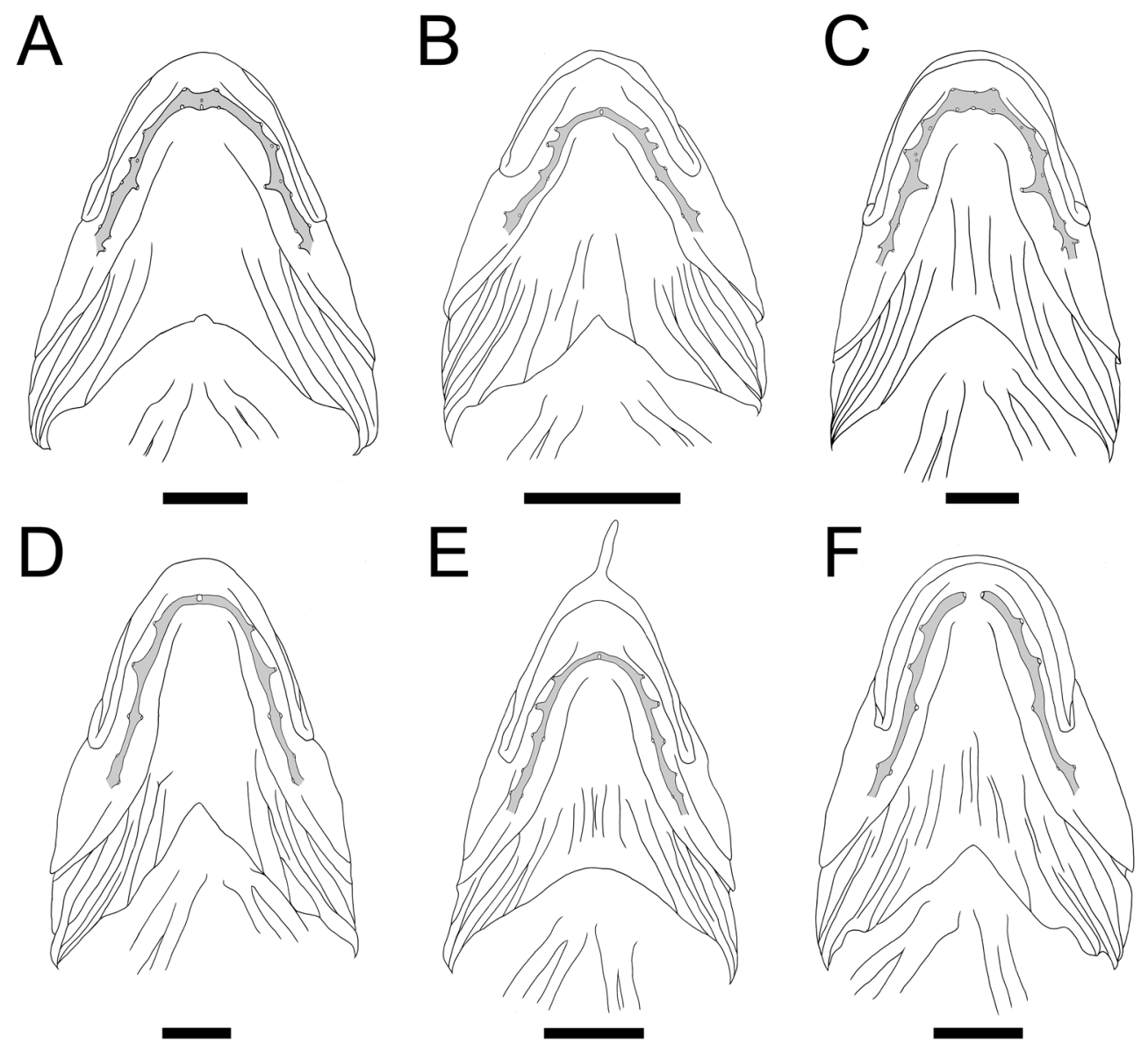

Fig. 6. Mandibular sensory pore system of species of Helcogramma in the Ryukyu Islands. A, Helcogramma aquila (HMNH-P 9148, male, $34.4 \mathrm{~mm} \mathrm{SL}$ ); B, H. fuscipectoris (KAUM-I. 24444, male, $28.7 \mathrm{~mm} \mathrm{SL}$ ); C, H. inclinata (KAUM-I. 6522, male, $50.9 \mathrm{~mm} \mathrm{SL}$ ); D. H. ishigakiensis (KAUM-I. 17519, male, $50.0 \mathrm{~mm} \mathrm{SL}$ ); E, H. rhinoceros (KAUM-I. 32332, male, $26.9 \mathrm{~mm} \mathrm{SL}$ ); F, H. striata (KAUM-I. 30110, male, 37.1 mm SL). Scale bars $2 \mathrm{~mm}$.

(Okinoerabu-jima and Okinawa-jima islands, Ryukyu Islands).

Helcogramma inclinata (not of Fowler, 1946): Yoshigou and Nakamura 2008: 70 (in part; HMNH-P 4409 and 91439148 from Okinawa-jima island, Ryukyu Islands).

Helcogramma sp.: Yoshigou and Nakamura 2008: 71 (in part; HMNH-P 8003 from Okinoerabu-jima island, Ryukyu Islands).

Material examined. 8 specimens, $32.5-40.8 \mathrm{~mm} \mathrm{SL}$, as listed in Tashiro and Motomura (2013).

Diagnosis. A species of Helcogramma with the following combination of characters: 13 (rarely 14) second dorsalfin spines; 24-31 pored lateral-line scales; 5-7 symphyseal mandibular pores; anterior nostril tentacle unbranched; orbital tentacle simple; nape without scales; lower half of head (area bounded by snout, ventral margin of orbit, and preopercular margin) black; bright blue stripe extending from anterior part of upper lip, through ventral margin of orbit, to preopercular margin; dorsal fins black distally; central part of pectoral-fin base black; entire caudal fin black (all color descriptions for mature males only).

Distribution. Helcogramma aquila is distributed in the western Pacific Ocean, where it ranges from the Ryukyu
Islands to north of the Philippines, and east to the Mariana Islands (Fricke 1997; Myers and Donaldson 2003; Williams and Howe 2003; Tashiro and Motomura 2013). In the Ryukyu Islands, this species has been collected from Okinoerabu-jima and Okinawa-jima islands.

Remarks. Helcogramma aquila belongs to the H. fuscopinna species group, as is shown by the bright blue stripe on the head extending from the anterior part of the upper lip, through the ventral margin of the orbit, to the preopercular margin in mature males (Williams and Howe 2003). A detailed description and comparisons with other species of the group were given by Tashiro and Motomura (2013).

Helcogramma fuscipectoris (Fowler, 1946)

[Standard Japanese name: Kuromasuku]

(Figs 5C-D, 6B; Table 2)

Enneapterygius fuscipectoris Fowler, 1946: 187, figs 50-51 (type locality: Aguni-jima island, Ryukyu Islands).

Enneapterygius personatus Fowler, 1946: 185, figs 48-49 (type locality: Aguni-jima island, Ryukyu Islands).

Enneapterygius quadrimaculatus Fowler, 1946: 189, fig. 54 (type locality: Aguni-jima island, Ryukyu Islands).

Helcogramma obtusirostris (not of Klunzinger, 1871): Han- 
sen 1986: 341 (Okinawa-jima island, Ryukyu Islands); Hayashi 1993: 946 (southern Japan).

Helcogramma fuscipectoris: Fricke 1997: 430, fig. 86 (Okinawa-jima island, Ryukyu Islands); Hayashi 2000: 1080 (southern Japan); Watai et al. 2009: 129 (Tokashiki-jima island, Ryukyu Islands); Hayashi 2013: 1283, 2098 (Yakushima and Okinawa-jima islands, Ryukyu Islands).

Helcogramma obtusirostre (not of Klunzinger, 1871): Motomura et al. 2010: 189, fig. 435 (Yaku-shima island, Ryukyu Islands).

Type material examined. Enneapterygius fuscipectoris: ANSP 72060 (holotype), male, $22.2 \mathrm{~mm} \mathrm{SL}$, ANSP 72061 (paratype), male, $21.6 \mathrm{~mm} \mathrm{SL}$, Aguni-jima island, Ryukyu Islands, E. Tinkham, 27 July 1945. Enneapterygius personatus: ANSP 72057 (holotype), male, $20.0 \mathrm{~mm} \mathrm{SL}$, same data as for holotype of Enneapterygius fuscipectoris. Enneapterygius quadrimaculatus: ANSP 72066 (holotype), female, $18.9 \mathrm{~mm} \mathrm{SL}$, same data as for holotype of Enneapterygius fuscipectoris.

Non-type material examined. 42 specimens, 14.3$28.7 \mathrm{~mm}$ SL, all from the Ryukyu Islands. YAKU-SHIMA ISLAND: KAUM-I. 11240, male, $18.6 \mathrm{~mm}$ SL, KAUM-I. 11241, male, $14.8 \mathrm{~mm}$ SL, KAUM-I. 11764, male, $22.3 \mathrm{~mm}$ SL, KAUM-I. 11765, male, $22.3 \mathrm{~mm}$ SL, KAUM-I. 11766, female, $21.3 \mathrm{~mm} \mathrm{SL}$, south of Kamazenohana, Kurio, $30^{\circ} 15^{\prime} 57^{\prime \prime} \mathrm{N}, 130^{\circ} 24^{\prime} 52^{\prime \prime} \mathrm{E}, 3 \mathrm{~m}$ depth, KAUM Fish Team, 10 August 2008; KAUM-I. 11361, male, 27.9 mm SL, KAUM-I. 11432, male, $23.3 \mathrm{~mm}$ SL, KAUM-I. 11433, female, $21.8 \mathrm{~mm}$ SL, KAUM-I. 11739, male, $24.1 \mathrm{~mm}$ SL, KAUM-I. 11740, male, $21.3 \mathrm{~mm} \mathrm{SL}$, KAUM-I. 11741, female, $20.8 \mathrm{~mm}$ SL, KAUM-I. 11742, female, $22.1 \mathrm{~mm}$ SL, west of Kamazenohana, Kurio, $30^{\circ} 16^{\prime} 03^{\prime \prime} \mathrm{N}, 130^{\circ} 24^{\prime} 47^{\prime \prime} \mathrm{E}, 3 \mathrm{~m}$ depth, KAUM Fish Team, 12 August 2008; KAUM-I. 23543, female, $21.6 \mathrm{~mm}$ SL, KAUM-I. 24444, female, 28.7 mm SL, KAUM-I. 24445, female, $21.4 \mathrm{~mm}$ SL, KAUM-I. 24446, female, $21.9 \mathrm{~mm}$ SL, KAUM-I. 24447, male, $15.9 \mathrm{~mm}$ SL, west of Kamazenohana, Kurio, $30^{\circ} 16^{\prime} 03^{\prime \prime} \mathrm{N}, 130^{\circ} 24^{\prime} 47^{\prime \prime} \mathrm{E}, 3 \mathrm{~m}$ depth, KAUM Fish Team, 30 July 2009. NAKANO-SHIMA ISLAND: KAUM-I. 63398, male, $22.6 \mathrm{~mm}$ SL, KAUM-I. 63399, female, $24.2 \mathrm{~mm}$ SL, KAUM-I. 63400, male, $15.2 \mathrm{~mm}$ SL, west side of Nakano-shima Port, $29^{\circ} 50^{\prime} 29^{\prime \prime} \mathrm{N}, 129^{\circ} 50^{\prime} 39^{\prime \prime} \mathrm{E}$, $2 \mathrm{~m}$ depth, S. Tashiro, 1 September 2014. YORON-JIMA ISLAND: KAUM-I. 39909, male, $23.8 \mathrm{~mm}$ SL, KAUM-I. 39910, female, $20.3 \mathrm{~mm}$ SL, KAUM-I. 39915, female, 17.9 mm SL, KAUM-I. 39922, male, 19.4 mm SL, KAUM-I. 39923, female, $14.3 \mathrm{~mm}$ SL, KAUM-I. 39925, male, $17.0 \mathrm{~mm}$ SL, Mugiya, $27^{\circ} 01^{\prime} 18^{\prime \prime} \mathrm{N}, 128^{\circ} 26^{\prime} 21^{\prime \prime} \mathrm{E}, 0.5-1 \mathrm{~m}$ depth, M. Matsunuma, 12 August 2011; KAUM-I. 45932, female, $14.3 \mathrm{~mm}$ SL, tidepool near Yoron Port, $27^{\circ} 03^{\prime} 40^{\prime \prime} \mathrm{N}$, $128^{\circ} 25^{\prime} 02^{\prime \prime} \mathrm{E}, 0.5 \mathrm{~m}$ depth, S. Tashiro et al., 18 April 2012; KAUM-I. 46094, female, $28.0 \mathrm{~mm}$ SL, tidepool near Yoron Port, $27^{\circ} 03^{\prime} 40^{\prime \prime} \mathrm{N}, 128^{\circ} 25^{\prime} 02^{\prime \prime} \mathrm{E}, 0.5 \mathrm{~m}$ depth, KAUM Fish Team, 21 April 2012; KAUM-I. 47824, male, $21.8 \mathrm{~mm}$ $\mathrm{SL}$, off Maehama Beach, $27^{\circ} 01^{\prime} 13^{\prime \prime} \mathrm{N}, 128^{\circ} 24^{\prime} 29^{\prime \prime} \mathrm{E}, 2-8 \mathrm{~m}$ depth, KAUM Fish Team, 13 August 2012; KAUM-I. 50840, male, $23.1 \mathrm{~mm}$ SL, KAUM-I. 50846, male, $20.2 \mathrm{~mm}$ SL, KAUM-I. 50847, male, $20.5 \mathrm{~mm} \mathrm{SL}$, Chabana, $27^{\circ} 03^{\prime} 40^{\prime \prime} \mathrm{N}$, $128^{\circ} 25^{\prime} 02^{\prime \prime} \mathrm{E}, 3 \mathrm{~m}$ depth, KAUM Fish Team, 20 August 2012; KAUM-I. 51242, male, $22.0 \mathrm{~mm} \mathrm{SL}$, Chabana, $27^{\circ} 03^{\prime} 40^{\prime \prime} \mathrm{N}$, $128^{\circ} 25^{\prime} 02^{\prime \prime} \mathrm{E}, 2 \mathrm{~m}$ depth, KAUM Fish Team, 23 October 2012. OKINAWA-JIMA ISLAND: KAUM-I. 10102, male, $26.3 \mathrm{~mm}$ SL, KAUM-I. 10103, male, $28.7 \mathrm{~mm} \mathrm{SL}$, tidepools at Minatogawa, Yaese, $26^{\circ} 07^{\prime} 10^{\prime \prime} \mathrm{N}, 127^{\circ} 45^{\prime} 21^{\prime \prime} \mathrm{E}$, KAUM Fish Team, 23 May 2008. TOKASHIKI-JIMA ISLAND: KPM-NI 22673, male, $28.2 \mathrm{~mm}$ SL, KPM-NI 22675, male, $28.2 \mathrm{~mm}$ SL, off Tokashiku Beach, 23 February 2007. ISHIGAKI-JIMA ISLAND: KAUM-I. 53873, male, $27.5 \mathrm{~mm}$ SL, KAUM-I. 53875, male, $27.1 \mathrm{~mm}$ SL, tidepool, Yonehara Beach, $24^{\circ} 26^{\prime} 57^{\prime \prime} \mathrm{N}, 124^{\circ} 10^{\prime} 41^{\prime \prime} \mathrm{E}$, T. Yoshida and H. Nishiyama, 9 April 2013. MINAMIDAITO-JIMA ISLAND: KAUM-I. 49922, male, $24.3 \mathrm{~mm}$ SL, KAUM-I. 49923, female, $22.6 \mathrm{~mm}$ SL, KAUM-I. 49949, male, $25.0 \mathrm{~mm}$ SL, coast of Honba, $27^{\circ} 03^{\prime} 40^{\prime \prime} \mathrm{N}, 128^{\circ} 25^{\prime} 02^{\prime \prime} \mathrm{E}, 4-7 \mathrm{~m}$ depth, K. Kuriiwa, 25 June 2012.

Diagnosis. A species of Helcogramma with the following combination of characters: 14-15 (rarely 15) second dorsal-fin spines; 9-11 (usually 10) third dorsal-fin rays; 19-25 pored lateral-line scales; $4+1+4$ mandibular pores; anterior nostril tentacle branched (unbranched in smaller specimens); orbital tentacle simple; nape without scales; bright blue stripe extending from posterior part of upper lip, through ventral margin of orbit, to preopercular margin; pectoral-fin base black; lower 7 or 8 pectoral-fin rays dusky (all color descriptions pertaining to mature males only).

Distribution. Helcogramma fuscipectoris is distributed in the western Pacific Ocean, where it ranges from southern Japan to Indonesia, and also Vanuatu (Fricke 1997). In the Ryukyu Islands, this species was collected in the present study from Yaku-shima, Nakano-shima, Yoron-jima, Okinawa-jima, Tokashiki-jima, Ishigaki-jima, and Minamidaitojima islands. It mainly inhabits rock surfaces at depths of $0.5-3 \mathrm{~m}$.

Remarks. Enneapterygius fuscipectoris was originally described by Fowler (1946) from Aguni-jima island in the Ryukyu Islands. In the same paper, Fowler (1946) also described Enneapterygius personatus and E. quadrimaculatus as new species from this island. Fricke (1997) regarded these three nominal species as identical, and E. fuscipectoris as the senior synonym of the latter two names. Hansen (1986) redescribed Helcogramma obtusirostre (Klunzinger, 1871), originally described from Al-Qusair, Egypt, the Red Sea, as a senior synonym of E. fuscipectoris, and reported it as occurring in the Indo-Pacific Ocean. Subsequently, Fricke (1997) redescribed Helcogramma fuscipectoris as a valid species restricted to the western Pacific, and $H$. obtusirostre as a western Indian Ocean species. Mature males of $H$. fuscipectoris can be easily distinguished from $H$. obtusirostre by their usually having 14 second dorsal-fin spines (vs 12-13 in the latter species) and a pale reddish body except for the black pectoral-fin base ( $v s$ a dusky or blackish body except for a reddish area around the pectoral-fin base and abdomen) [data for H. obtusirostre from Holleman (2007) and this study]. 


\author{
Helcogramma inclinata (Fowler, 1946) \\ [Standard Japanese name: Aya-hebigimpo] \\ (Figs 5E-F, 6C; Table 2)
}

Enneapterygius inclinatus Fowler, 1946: 191, fig. 55 (type locality: Aguni-jima island, Ryukyu Islands).

Helcogramma habena Williams and McCormick, 1990: 1020, figs 2, 6A-B, 8 (type locality: Batan Island, Batan Islands, Philippines).

Helcogramma ellioti (not of Herre, 1944): Hayashi 1993: 944 (Ryukyu Islands); Hayashi 2000: 1079 (Ryukyu Islands); Kato 2011: 222, unnumbered fig. (Yaku-shima island, Ryukyu Islands).

Helcogramma fuscopinna (not of Holleman, 1982): Aizawa 1997: 560, unnumbered fig. (Iriomote-jima island, Ryukyu Islands).

Helcogramma inclinatum: Fricke 1997: 446, fig. 91 (Ishigaki-jima island, Ryukyu Islands); Hayashi 2013: 1282, unnumbered fig. (Yaku-shima and Aguni-jima islands, Ryukyu Islands).

Helcogramma inclinata: Williams and Howe 2003: 164 (Aguni-jima island, Ryukyu Islands); Senou et al. 2006: 84 (Ie-jima island, Ryukyu Islands); Motomura et al. 2006: 107, figs 2-4 (Satsuma Peninsula, Kyushu; Yaku-shima island, Ryukyu Islands); Yoshigou and Nakamura 2008: 70 (in part; HMNH-P 5739, 7425, 7426, 8625, and 9023 from Kume-jima and Okinawa-jima islands, Ryukyu Islands); Motomura et al. 2010: 188, fig. 434 (Yaku-shima island, Ryukyu Islands); Tashiro 2013: 294, unnumbered figs (Iou-jima and Take-shima islands, Ryukyu Islands).

Helcogramma nesion (not of Williams and Howe, 2003): Yoshigou and Nakamura 2008: 71 (in part; HMNH-P 7945 from Okinawa-jima island, Ryukyu Islands).

Helcogramma sp.: Yoshigou and Nakamura 2008: 71 (in part; HMNH-P 7910 from Okinoerabu-jima island, Ryukyu Islands).

Type material examined. Enneapterygius inclinatus: ANSP 72067 (holotype), male, $26.1 \mathrm{~mm}$ SL, Aguni-jima island, Ryukyu Islands, E. Tinkham, 27 July 1945.

Non-type material examined. 107 specimens, $13.5-51.5 \mathrm{~mm}$ SL. SATSUMA PENINSULA, KYUSHU: KAUM-I. 4246, female, $50.0 \mathrm{~mm}$ SL, Kurose Beach, Kasasa, Minamisatsuma, $31^{\circ} 22^{\prime} 29^{\prime \prime} \mathrm{N}, 130^{\circ} 10^{\prime} 09^{\prime \prime} \mathrm{E}, 2 \mathrm{~m}$ depth, M. Ito, 28 May 2007; KAUM-I. 6522, male, $50.9 \mathrm{~mm}$ SL, KAUM-I. 6576, male, $43.0 \mathrm{~mm}$ SL, Kurose Beach, Kasasa, Minamisatsuma, $31^{\circ} 22^{\prime} 29^{\prime \prime} \mathrm{N}, 130^{\circ} 10^{\prime} 09^{\prime \prime} \mathrm{E}, 2 \mathrm{~m}$ depth, M. Ito, 9 September 2007. TAKE-SHIMA ISLAND: KAUM-I. 29668, male, 43.9 mm SL, KAUM-I. 29669, male, $42.5 \mathrm{~mm}$ SL, KAUM-I. 29683, male, $13.8 \mathrm{~mm}$ SL, KAUM-I. 29684, female, $15.2 \mathrm{~mm} \mathrm{SL}$, off south coast of Ombozaki, $30^{\circ} 48^{\prime} 32^{\prime \prime} \mathrm{N}, 130^{\circ} 24^{\prime} 33^{\prime \prime} \mathrm{E}$, 5-20 m depth, KAUM Fish Team, 29 May 2010; KAUM-I. 37989, male, $45.6 \mathrm{~mm}$ SL, off south coast of Ombozaki, $30^{\circ} 48^{\prime} 32^{\prime \prime} \mathrm{N}, 130^{\circ} 24^{\prime} 33^{\prime \prime} \mathrm{E}$, 5-20 m depth, KAUM Fish Team, 18 May 2011. IOU-JIMA ISLAND: KAUM-I. 29529, male, $13.5 \mathrm{~mm} \mathrm{SL}$, off west coast, $30^{\circ} 47^{\prime} 04^{\prime \prime} \mathrm{N}, 130^{\circ} 15^{\prime} 42^{\prime \prime} \mathrm{E}, 5-20 \mathrm{~m}$ depth, KAUM Fish Team, 25 May 2010; KAUM-I. 29592, male, $17.9 \mathrm{~mm}$
SL, off west coast, $30^{\circ} 47^{\prime} 04^{\prime \prime} \mathrm{N}, 130^{\circ} 15^{\prime} 42^{\prime \prime} \mathrm{E}, 5-20 \mathrm{~m}$ depth, KAUM Fish Team, 28 May 2010; KAUM-I. 30625, female, $49.2 \mathrm{~mm} \mathrm{SL}$, KAUM-I. 30626, male, $31.3 \mathrm{~mm} \mathrm{SL}$, off west coast, $30^{\circ} 47^{\prime} 04^{\prime \prime} \mathrm{N}, 130^{\circ} 15^{\prime} 42^{\prime \prime} \mathrm{E}, 2-22 \mathrm{~m}$ depth, KAUM Fish Team, 27 June 2010; KAUM-I. 37834, male, $44.2 \mathrm{~mm}$ SL, Harumase, $30^{\circ} 46^{\prime} 19^{\prime \prime} \mathrm{N}, 130^{\circ} 16^{\prime} 51^{\prime \prime} \mathrm{E}, 10-15 \mathrm{~m}$ depth, KAUM Fish Team, 16 May 2011. YAKU-SHIMA ISLAND: KAUM-I. 34, male, $44.3 \mathrm{~mm}$ SL, Isso, $30^{\circ} 27^{\prime} 26^{\prime \prime} \mathrm{N}$, $130^{\circ} 29^{\prime} 18^{\prime \prime} \mathrm{E}, 3 \mathrm{~m}$ depth, S. Harazaki, 20 January 2006; KAUM-I. 11189, male, $43.1 \mathrm{~mm}$ SL, KAUM-I. 11190, female, $42.7 \mathrm{~mm}$ SL, KAUM-I. 11242, female, $44.0 \mathrm{~mm}$ SL, KAUM-I. 11243, female, $41.0 \mathrm{~mm}$ SL, KAUM-I. 11763 , male, $32.3 \mathrm{~mm}$ SL, south of Kamazenohana, Kurio, $30^{\circ} 16^{\prime} 03^{\prime \prime} \mathrm{N}, 130^{\circ} 24^{\prime} 52^{\prime \prime} \mathrm{E}, 0-3 \mathrm{~m}$ depth, KAUM Fish Team, 10 August 2008; KAUM-I. 11424, male, $50.8 \mathrm{~mm} \mathrm{SL}$, KAUM-I. 11425, female, $50.3 \mathrm{~mm}$ SL, KAUM-I. 11426, male, $34.4 \mathrm{~mm}$ SL, KAUM-I. 11427, female, $36.5 \mathrm{~mm}$ SL, KAUM-I. 11428, female, 24.9 mm SL, KAUM-I. 11731, female, $28.0 \mathrm{~mm}$ SL, KAUM-I. 11732, female, $46.6 \mathrm{~mm}$ SL, KAUM-I. 11733, female, $36.5 \mathrm{~mm}$ SL, KAUM-I. 11734, female, $32.2 \mathrm{~mm}$ SL, KAUM-I. 11735, female, $42.7 \mathrm{~mm} \mathrm{SL}$, KAUM-I. 11736, female, $51.5 \mathrm{~mm}$ SL, KAUM-I. 11737, female, $26.5 \mathrm{~mm}$ SL, KAUM-I. 11738, female, $25.5 \mathrm{~mm}$ SL, KAUM-I. 24443, male, $21.7 \mathrm{~mm}$ SL, west of Kamazenohana, Kurio, $30^{\circ} 15^{\prime} 57^{\prime \prime} \mathrm{N}, 130^{\circ} 24^{\prime} 47^{\prime \prime} \mathrm{E}, 0-3 \mathrm{~m}$ depth, KAUM Fish Team, 12 August 2008; KAUM-I. 11472, female, $26.1 \mathrm{~mm}$ SL, KAUM-I. 11473, female, 22.9 mm SL, KAUM-I. 11474, male, $29.9 \mathrm{~mm}$ SL, KAUM-I. 11478, male, $23.9 \mathrm{~mm}$ SL, Isso, $30^{\circ} 27^{\prime} 23^{\prime \prime} \mathrm{N}, 130^{\circ} 29^{\prime} 59^{\prime \prime} \mathrm{E}, 1-5 \mathrm{~m}$ depth, KAUM Fish Team, 13 August 2008; KAUM-I. 20192, male, 28.8 mm SL, KAUM-I. 20209, male, $34.8 \mathrm{~mm}$ SL, tide pool at west of Yudomari Port, Yudomari, $30^{\circ} 13^{\prime} 58^{\prime \prime} \mathrm{N}, 130^{\circ} 28^{\prime} 19^{\prime \prime} \mathrm{E}, 0-3 \mathrm{~m}$ depth, KAUM Fish Team, 29 October 2008; KAUM-I. 20348, male, $28.0 \mathrm{~mm}$ SL, KAUM-I. 20350, male, $30.6 \mathrm{~mm}$ SL, KAUM-I. 20351, male, $39.7 \mathrm{~mm}$ SL, southeast of Cape Yahazu, Isso, $30^{\circ} 27^{\prime} 27^{\prime \prime} \mathrm{N}, 130^{\circ} 30^{\prime} 02^{\prime \prime} \mathrm{E}, 1-3 \mathrm{~m}$ depth, KAUM Fish Team, 31 October 2008; KAUM-I. 21857, male, $24.8 \mathrm{~mm}$ SL, KAUM-I. 21858, female, $23.3 \mathrm{~mm}$ SL, west of Kamazenohana, Kurio, $30^{\circ} 15^{\prime} 57^{\prime \prime} \mathrm{N}, 130^{\circ} 24^{\prime} 47^{\prime \prime} \mathrm{E}, 0-4 \mathrm{~m}$ depth, KAUM Fish Team, 30 July 2009; KAUM-I. 38696, male, $41.9 \mathrm{~mm} \mathrm{SL}$, south of Yudomari Port, Yudomari, $30^{\circ} 13^{\prime} 55^{\prime \prime} \mathrm{N}, 130^{\circ} 28^{\prime} 19^{\prime \prime} \mathrm{E}, 1-5 \mathrm{~m}$ depth, KAUM Fish Team, 11 June 2011. NAKANO-SHIMA ISLAND: YCM-P 26990, tidepool at Funakura, M. Hayashi, 3 May 1992. TAKARAJIMA ISLAND: KAUM-I. 2037, male, $39.4 \mathrm{~mm} \mathrm{SL,} 25$ March 1965. AMAMI-OSHIMA ISLAND: KAUM-I. 4126, male, $35.1 \mathrm{~mm} \mathrm{SL,} 4$ May 1965; KAUM-I. 17495, male, $44.1 \mathrm{~mm}$ SL, KAUM-I. 17496, female, $44.1 \mathrm{~mm}$ SL, tidepool at Tsuchihama, Kasari, $28^{\circ} 24^{\prime} 34^{\prime \prime} \mathrm{N}, 129^{\circ} 40^{\prime} 31^{\prime \prime} \mathrm{E}$, 0.5-1 $\mathrm{m}$ depth, M. Meguro and T. Yoshida, 27 March. 2009. OKINOERABU-JIMA ISLAND: HMNH-P 7910, male, $41.1 \mathrm{~mm}$ SL, female, $37.8 \mathrm{~mm}$ SL, Okidomari Beach, Tina, 2 May 2004; KAUM-I. 2002, male, $49.1 \mathrm{~mm}$ SL, July 1962. YORON-JIMA ISLAND: KAUM-I. 40069, male, $20.1 \mathrm{~mm}$ SL, off Udonosu Beach, $27^{\circ} 03^{\prime} 43^{\prime \prime} \mathrm{N}, 128^{\circ} 25^{\prime} 02^{\prime \prime} \mathrm{E}$, 0.3-1 m depth, M. Matsunuma, 14 August 2011; KAUM-I. 40103, male, $20.9 \mathrm{~mm}$ SL, KAUM-I. 40397, male, $41.5 \mathrm{~mm}$ SL, KAUM-I. 44370, male, 32.3 mm SL, KAUM-I. 44371, 
male, $26.1 \mathrm{~mm}$ SL, KAUM-I. 44372, female, $24.9 \mathrm{~mm}$ SL, KAUM-I. 44373, male, $24.6 \mathrm{~mm}$ SL, KAUM-I. 44374, female, $21.8 \mathrm{~mm} \mathrm{SL}$, off southwest coast, $27^{\circ} 01^{\prime} 48^{\prime \prime} \mathrm{N}$, $128^{\circ} 24^{\prime} 37^{\prime \prime} \mathrm{E}, 2-10 \mathrm{~m}$ depth, M. Meguro and E. Katayama, 17 August 2011; KAUM-I. 45757, male, $33.1 \mathrm{~mm} \mathrm{SL}$, off Tomori Fishing Port, $27^{\circ} 01^{\prime} 54^{\prime \prime} \mathrm{N}, 128^{\circ} 24^{\prime} 29^{\prime \prime} \mathrm{E}, 5-10$ $\mathrm{m}$ depth, M. Yamashita and T. Yoshida, 15 April 2012; KAUM-I. 45832, male, $34.8 \mathrm{~mm}$ SL, off Maehama Beach, $27^{\circ} 01^{\prime} 13^{\prime \prime} \mathrm{N}, 128^{\circ} 24^{\prime} 29^{\prime \prime} \mathrm{E}, 5 \mathrm{~m}$ depth, H. Motomura, 16 April 2012; KAUM-I. 45861, male, 36.8 mm SL, KAUM-I. 45895, male, $35.1 \mathrm{~mm}$ SL, KAUM-I. 45896, male, $31.3 \mathrm{~mm}$ SL, off Maehama Beach, $27^{\circ} 01^{\prime} 13^{\prime \prime} \mathrm{N}, 128^{\circ} 24^{\prime} 29^{\prime \prime} \mathrm{E}, 3-10 \mathrm{~m}$ depth, KAUM Fish Team, 17 April 2012; KAUM-I. 47823, male, $42.2 \mathrm{~mm} \mathrm{SL}$, off Maehama Beach, $27^{\circ} 01^{\prime} 13^{\prime \prime} \mathrm{N}$, $128^{\circ} 24^{\prime} 29^{\prime \prime} \mathrm{E}, 2-8 \mathrm{~m}$ depth, KAUM Fish Team, $13 \mathrm{Au}-$ gust 2012; KAUM-I. 47878, male, $39.8 \mathrm{~mm}$ SL, Chabana, $27^{\circ} 03^{\prime} 40^{\prime \prime} \mathrm{N}, 128^{\circ} 25^{\prime} 02^{\prime \prime} \mathrm{E}, 2 \mathrm{~m}$ depth, KAUM Fish Team, 13 August 2012; KAUM-I. 48144, male, $28.5 \mathrm{~mm}$ SL, off Maehama Beach, $27^{\circ} 01^{\prime} 13^{\prime \prime} \mathrm{N}, 128^{\circ} 24^{\prime} 29^{\prime \prime} \mathrm{E}, 1 \mathrm{~m}$ depth, KAUM Fish Team, 19 August 2012; KAUM-I. 50844, male, $22.8 \mathrm{~mm}$ SL, KAUM-I. 50848, male, 26.7 mm SL, KAUM-I. 50850, female, $23.0 \mathrm{~mm}$ SL, KAUM-I. 50851, female, $23.0 \mathrm{~mm}$ SL, KAUM-I. 50852, male, $20.9 \mathrm{~mm}$ SL, Chabana, $27^{\circ} 03^{\prime} 40^{\prime \prime} \mathrm{N}$, $128^{\circ} 25^{\prime} 02^{\prime \prime} \mathrm{E}, 2-3 \mathrm{~m}$ depth, KAUM Fish Team, $20 \mathrm{Au}-$ gust 2012; KAUM-I. 50863, male, $38.0 \mathrm{~mm}$ SL, Chabana, $27^{\circ} 03^{\prime} 40^{\prime \prime} \mathrm{N}, 128^{\circ} 25^{\prime} 02^{\prime \prime} \mathrm{E}, 15-17 \mathrm{~m}$ depth, KAUM Fish Team, 21 August 2012; KAUM-I. 51239, female, $30.1 \mathrm{~mm}$ SL, KAUM-I. 51243, female, $31.3 \mathrm{~mm} \mathrm{SL}$, off Maehama Beach, $27^{\circ} 01^{\prime} 13^{\prime \prime} \mathrm{N}, 128^{\circ} 24^{\prime} 29^{\prime \prime} \mathrm{E}, 3-5 \mathrm{~m}$ depth, KAUM Fish Team, 23 October 2012; KAUM-I. 51241, male, $37.6 \mathrm{~mm} \mathrm{SL}$, Chabana, $27^{\circ} 03^{\prime} 40^{\prime \prime} \mathrm{N}, 128^{\circ} 25^{\prime} 02^{\prime \prime} \mathrm{E}, 2 \mathrm{~m}$ depth, KAUM Fish Team, 23 October 2012; KAUM-I. 51339, male, $27.4 \mathrm{~mm}$ SL, off Ritcho, $27^{\circ} 01^{\prime} 20^{\prime \prime} \mathrm{N}, 128^{\circ} 25^{\prime} 47^{\prime \prime} \mathrm{E}, 10 \mathrm{~m}$ depth, KAUM Fish Team, 24 October 2012; KAUM-I. 51376, female, $29.7 \mathrm{~mm}$ SL, Chabana, $27^{\circ} 03^{\prime} 40^{\prime \prime} \mathrm{N}, 128^{\circ} 25^{\prime} 02^{\prime \prime} \mathrm{E}$, $8 \mathrm{~m}$ depth, KAUM Fish Team, 25 October 2012; KAUM-I. 51399, male, $34.1 \mathrm{~mm}$ SL, KAUM-I. 51400, male, $25.5 \mathrm{~mm}$ SL, KAUM-I. 51401, male, $24.1 \mathrm{~mm}$ SL, Chabana, $27^{\circ} 03^{\prime} 40^{\prime \prime} \mathrm{N}, 128^{\circ} 25^{\prime} 02^{\prime \prime} \mathrm{E}, 8 \mathrm{~m}$ depth, KAUM Fish Team, 26 October 2012; KAUM-I. 51455, female, $31.4 \mathrm{~mm} \mathrm{SL}$, KAUM-I. 51456, female, 28.6 mm SL, KAUM-I. 51457, female, $27.8 \mathrm{~mm}$ SL, KAUM-I. 51458, female, $23.5 \mathrm{~mm}$ SL, KAUM-I. 51558, male, 32.8 mm SL, KAUM-I. 51559, male, 36.7 mm SL, KAUM-I. 51560, male, 34.5 mm SL, KAUM-I. 51586, male, $39.0 \mathrm{~mm} \mathrm{SL}$, off Maehama Beach, $27^{\circ} 01^{\prime} 13^{\prime \prime} \mathrm{N}$, $128^{\circ} 24^{\prime} 29^{\prime \prime} \mathrm{E}, 2-8 \mathrm{~m}$ depth, KAUM Fish Team, 29 October 2012; KAUM-I. 51470, female, $30.5 \mathrm{~mm}$ SL, Chabana, $27^{\circ} 03^{\prime} 40^{\prime \prime} \mathrm{N}, 128^{\circ} 25^{\prime} 02^{\prime \prime} \mathrm{E}, 8 \mathrm{~m}$ depth, KAUM Fish Team, 27 October 2012. OKINAWA-JIMA ISLAND: HMNH-P 5515, male, $32.6 \mathrm{~mm}$ SL, Giizabanda, Asato, Yaese, $10 \mathrm{Au}-$ gust 2002; HMNH-P 7425, female, $42.7 \mathrm{~mm}$ SL, HMNH-P 7426, male, $30.0 \mathrm{~mm}$ SL, Komesu Beach, Itoman, 27 December 2003; HMNH-P 8625, 2 males, 36.4-45.7 mm SL, 3 females, 32.0-40.5 mm SL, Odo Beach, Itoman, 12 December 2004; HMNH-P 9023, 3 females, 34.3-38.2 mm SL, Akasaki Beach, Kunigami, 31 December 2005. KUME-JIMA ISLAND: HMNH-P 5739, male, $22.1 \mathrm{~mm}$ SL, beach near Kume Airport, 13 August 2002.
Diagnosis. A species of Helcogramma with the following combination of characters: 13-16 (rarely 13; usually 15) second dorsal-fin spines; $22-35$ pored lateral-line scales; 5-10 symphyseal mandibular pores; anterior nostril tentacle unbranched; orbital tentacle simple; nape scaled; lower half of head (area bounded by snout, ventral margin of orbit, and preopercular margin) black; bright blue stripe extending from anterior part of upper lip, through ventral margin of orbit, to preopercular margin; all fins and body black (all color descriptions for mature males only).

Distribution. Helcogramma inclinata is distributed in the western Pacific Ocean, where it ranges from southern Japan to the Philippines (Fricke 1997; Williams and Howe 2003). In Japan, this species has been collected from the Satsuma Peninsula in southern Kyushu and from Takeshima, Iou-jima, Yaku-shima, Nakano-shima, Takara-jima, Yoron-jima, Okinawa-jima, and Kume-jima islands in the Ryukyu Islands. In addition, this species has been recorded elsewhere in the central and southern Ryukyu Islands: i.e., Ie-jima (Senou et al. 2006), Aguni-jima (Fowler 1946), Ishigaki-jima (Fricke 1997), and Iriomote-jima (Aizawa 1997) islands. Helcogramma inclinata usually inhabits rocky reefs at depths of 3-8 m.

Remarks. Helcogramma inclinata, belonging to the H. fuscopinna species group (sensu Fricke 1997), is distinguished from all other members of the group by its usually having 15 second dorsal-fin rays, 5-10 symphyseal mandibular pores, and a scaled nape, and by its mature male coloration (e.g., lower head, body, and all fins black).

Motomura et al. (2006) reported $H$. inclinata from the southern end of the Satsuma Peninsula, on the basis of an underwater photograph only, as the northernmost record for the species. Two of our specimens (KAUM-I. 4246, $50.0 \mathrm{~mm}$ SL; KAUM-I. 6522, $50.9 \mathrm{~mm} \mathrm{SL}$ ) collected from Kasasa, Minamisatsuma, on the west coast of Satsuma Peninsula, represent a northward distributional range extension for H. inclinata.

Helcogramma rhinoceros Hansen, 1986
Standard Japanese name: Tengu-hebigimpo]

(Figs 5G-H, 6E; Table 2)

Helcogramma rhinoceros Hansen, 1986: 332, fig. 7 (left), 15 (type locality: Putic Island, Philippines); Aizawa 1997: 560, unnumbered fig. (Iriomote-jima island, Ryukyu Islands); Suzuki et al. 1998: 2, figs 1-7 (Nakano-ugan-jima and Iriomote-jima islands, Ryukyu Islands); Motomura et al. 2010: 189, fig. 436 (Yaku-shima island, Ryukyu Islands); Kato 2011: 221, unnumbered fig. (Yaku-shima island, Ryukyu Islands); Tashiro 2013: 298, unnumbered figs (Take-shima island, Ryukyu Islands); Hayashi 2013; 1283, 2098 (Yaku-shima, Amami-oshima, and Okinawajima islands, Ryukyu Islands).

Non-type material examined. 12 specimens, 21.1$30.3 \mathrm{~mm}$ SL. TAKE-SHIMA ISLAND: KAUM-I. 32332, male, $26.9 \mathrm{~mm} \mathrm{SL}$, off south coast of Ombozaki, $30^{\circ} 48^{\prime} 32^{\prime \prime} \mathrm{N}$, $130^{\circ} 24^{\prime} 33^{\prime \prime} \mathrm{E}, 5-10 \mathrm{~m}$ depth, KAUM Fish Team, 19 Septem- 
ber 2010. NAKANO-SHIMA ISLAND: KAUM-I. 63252, female, $30.3 \mathrm{~mm}$ SL, Nakano-shima Port, $29^{\circ} 50^{\prime} 14^{\prime \prime} \mathrm{N}$, $129^{\circ} 50^{\prime} 56^{\prime \prime} \mathrm{E}, 17-19 \mathrm{~m}$ depth, S. Tashiro, 30 August 2014; KAUM-I. 63467, female, $29.4 \mathrm{~mm}$ SL, south side of Nakano-shima Port, $29^{\circ} 50^{\prime} 13^{\prime \prime} \mathrm{N}, 129^{\circ} 51^{\prime} 03^{\prime \prime} \mathrm{E}, 5 \mathrm{~m}$ depth, S. Tashiro, 2 September 2014. AMAMI-OSHIMA ISLAND: KAUM-I. 57683, female, $21.2 \mathrm{~mm}$ SL, KAUM-I. 57729, female, $21.1 \mathrm{~mm}$ SL, $28^{\circ} 07^{\prime} 57^{\prime \prime} \mathrm{N}, 129^{\circ} 21^{\prime} 07^{\prime \prime} \mathrm{E}, 3-15 \mathrm{~m}$ depth, Sokaru, Setouchi, S. Tashiro et al., 13 December 2013. YORON-JIMA ISLAND: KAUM-I. 51381, $27.2 \mathrm{~mm}$ SL, off Yoron Port, $27^{\circ} 3^{\prime} 40^{\prime \prime} \mathrm{N}, 128^{\circ} 25^{\prime} 02^{\prime \prime} \mathrm{E}, 8 \mathrm{~m}$ depth, S. Tashiro, 26 October 2012; KAUM-I. 51428, male, $26.8 \mathrm{~mm}$ SL, KAUM-I. 51465, male, 26.7 mm SL, KAUM-I. 51466, male, 23.8 SL, off Yoron Port, $27^{\circ} 3^{\prime} 40^{\prime \prime} \mathrm{N}, 128^{\circ} 25^{\prime} 02^{\prime \prime} \mathrm{E}$, $8 \mathrm{~m}$ depth, S. Tashiro, 27 October 2012. ISHIGAKI-JIMA ISLAND: NSMT-P 55449, female, $25.2 \mathrm{~mm}$ SL, $23^{\circ} 26^{\prime} 60^{\prime \prime} \mathrm{N}$, $124^{\circ} 04^{\prime} 80^{\prime \prime} \mathrm{E}$, Uganzaki, K. Matsuura et al., 24 February 1998. NAKANOUGAN-JIMA ISLAND: KPM-NI 4341, male, $26.1 \mathrm{~mm}$ SL, KPM-NI 4342, female, $23.6 \mathrm{~mm}$ SL, K. Yano, 28 July 1997.

Diagnosis. A species of Helcogramma with the following combination of characters: $14-15$ (modally 15) second dorsal-fin spines; 19-24 pored lateral-line scales; 10-11 third dorsal-fin rays; $4+1+4$ mandibular pores; nape without scales; anterior nostril tentacle unbranched; orbital tentacle present; males with dermal prolongation on tip of snout; lower half of head (area below level of upper lip) black; narrow blue stripe running along upper lip, through ventral margin of orbit, to preopercular margin; pelvic fin, pectoral-fin base, and lower 7 pectoral-fin rays black (all color descriptions for mature males only).

Distribution. Helcogramma rhinoceros is distributed in the eastern Indian Ocean and western Pacific Ocean, where it ranges from the Andaman Sea to southern Japan, Vietnam, Indonesia, New Caledonia, and Vanuatu (Hansen 1986; Fricke 1997; Suzuki et al. 1998). In the Ryukyu Islands, this species was collected from Take-shima, Nakanoshima, Amami-oshima, Yoron-jima, Ishigaki-jima, and Nakano-ugan-jima islands during this study and had been previously recorded from Yaku-shima (Motomura et al. 2010) and Iriomote-jima (Aizawa 1997) islands. It was also confirmed from Kume-jima island (KPM-NR 36216, 64513, 64515) on the basis of underwater photographs. Helcogramma rhinoceros has been usually observed near the upper or lateral surfaces of rocks, at depths of 6-8 m.

Remarks. Mature males of Helcogramma rhinoceros can be distinguished easily from all other species of Helcogramma by their having a dermal prolongation on the tip of the snout. Females of $H$. rhinoceros are similar to females of $H$. fuscipectoris in coloration, but $H$. rhinoceros differs from the latter in having a simple anterior nostril tentacle (a branched tentacle in $H$. fuscipectoris).

Helcogramma striata Hansen, 1986

[Standard Japanese name: Tatejima-hebigimpo] (Figs 5I-J, 6E; Table 2)

Helcogramma striata Hansen, 1986: 350, fig. 18 (type locali- ty: Miyake-jima island, Izu Islands, Japan; paratypes from Tokomasari Reef, Okinawa-jima island, Ryukyu Islands); Aizawa 1997: 559, unnumbered fig. (Iriomote-jima island, Ryukyu Islands); Hayashi 2000: 945 (south of Amami-oshima island, Ryukyu Islands); Sakai et al. 2005: 10 (Nakano-shima island, Ryukyu Islands); Watai et al. 2009: 129 (Tokashiki-jima island, Ryukyu Islands); Motomura et al. 2010: 189, fig. 437 (Yaku-shima island, Ryukyu Islands); Tashiro 2013: 297, unnumbered figs (Iou-jima and Take-shima islands, Ryukyu Islands).

Helcogramma striatum: Fricke 1997: 481, fig. 98 (Ryukyu Islands); Senou et al. 2006: 84 (Ie-jima island, Ryukyu Islands); Senou et al. 2007: 64 (Miyako-jima island, Ryukyu Islands); Hayashi 2013: 1281, unnumbered fig. (Yakushima island and south of Amami-oshima island in the Ryukyu Islands).

Material examined. 29 specimens, $11.4-38.5 \mathrm{~mm}$ SL, from the Ryukyu Islands. TAKE-SHIMA ISLAND: KAUM-I. 29720, male, $18.9 \mathrm{~mm}$ SL, KAUM-I. 29721, $11.4 \mathrm{~mm} \mathrm{SL}$, off south coast of Ombozaki, $30^{\circ} 48^{\prime} 32^{\prime \prime} \mathrm{N}$, $130^{\circ} 24^{\prime} 33^{\prime \prime} \mathrm{E}, 5-40 \mathrm{~m}$ depth, KAUM Fish Team, 29 May 2010; KAUM-I. 30110, male, $37.1 \mathrm{~mm}$ SL, KAUM-I. 30111, male, $31.2 \mathrm{~mm}$ SL, KAUM-I. 30112, female, $20.3 \mathrm{~mm}$ SL, KAUM-I. 30113, male, $14.8 \mathrm{~mm} \mathrm{SL}$, off south coast of Ombozaki, $30^{\circ} 48^{\prime} 32^{\prime \prime} \mathrm{N}, 130^{\circ} 24^{\prime} 33^{\prime \prime} \mathrm{E}, 5-40 \mathrm{~m}$ depth, KAUM Fish Team, 27 May 2010; KAUM-I. 37748, male, $38.5 \mathrm{~mm}$ SL, KAUM-I. 37749, male, $36.7 \mathrm{~mm}$ SL, KAUM-I. 37750, male, $35.8 \mathrm{~mm}$ SL, KAUM-I. 37751, 2 males, 30.7$38.5 \mathrm{~mm}$ SL, 2 females, 28.8-29.3 mm SL, Take-shima Port, $30^{\circ} 48^{\prime} 59^{\prime \prime} \mathrm{N}, 130^{\circ} 25^{\prime} 06^{\prime \prime} \mathrm{E}, 3-5 \mathrm{~m}$ depth, KAUM Fish Team, 11 May 2011. IOU-JIMA ISLAND: KAUM-I. 29515, female, $33.5 \mathrm{~mm}$ SL, KAUM-I. 29516, male, $20.8 \mathrm{~mm} \mathrm{SL}$, off south coast, $30^{\circ} 46^{\prime} 32^{\prime \prime} \mathrm{N}, 130^{\circ} 16^{\prime} 43^{\prime \prime} \mathrm{E}, 10-60 \mathrm{~m}$ depth, KAUM Fish Team, 25 May 2010; KAUM-I. 30049, male, $13.6 \mathrm{~mm}$ SL, off west coast, $30^{\circ} 47^{\prime} 04^{\prime \prime} \mathrm{N}, 130^{\circ} 15^{\prime} 42^{\prime \prime} \mathrm{E}$, 5-20 m depth, KAUM Fish Team, 28 May 2010; KAUM-I. 31713, male, $27.6 \mathrm{~mm}$ SL, KAUM-I. 31714, male, $25.7 \mathrm{~mm}$ SL, off west coast, $30^{\circ} 47^{\prime} 04^{\prime \prime} \mathrm{N}, 130^{\circ} 15^{\prime} 42^{\prime \prime} \mathrm{E}, 10-15 \mathrm{~m}$ depth, KAUM Fish Team, 14 August 2010. YAKU-SHIMA ISLAND: KAUM-I. 20174, male, $20.4 \mathrm{~mm} \mathrm{SL}$, tide pool at west side Yudomari Port, $30^{\circ} 13^{\prime} 58^{\prime \prime} \mathrm{N}, 130^{\circ} 28^{\prime} 19^{\prime \prime} \mathrm{E}, 0-3 \mathrm{~m}$ depth, KAUM Fish Team, 29 October 2008. NAKANOSHIMA ISLAND: KAUM-I. 63256, male, $24.4 \mathrm{~mm}$ SL, KAUM-I. 63289, female, $21.7 \mathrm{~mm}$ SL, KAUM-I. 63290, male, $20.1 \mathrm{~mm}$ SL, KAUM-I. 63291, male, $13.8 \mathrm{~mm}$ SL, Nakano-shima Port, $29^{\circ} 50^{\prime} 14^{\prime \prime} \mathrm{N}, 129^{\circ} 50^{\prime} 56^{\prime \prime} \mathrm{E}, 17-19 \mathrm{~m}$ depth, S. Tashiro et al., 30 August 2014; KAUM-I. 63265, male, $23.6 \mathrm{~mm} \mathrm{SL}$, south side of Nakano-shima Port, $29^{\circ} 50^{\prime} 13^{\prime \prime} \mathrm{N}, 129^{\circ} 51^{\prime} 03^{\prime \prime} \mathrm{E}, 5 \mathrm{~m}$ depth, S. Tashiro et al., 2 September 2014. AMAMI-OSHIMA ISLAND: YCM-P 26162, male, $25.5 \mathrm{~mm}$ SL, Sakinome, Setouchi, Amami Fish Team, 27 August 1991. IE-JIMA ISLAND: KPM-NI 4110, male, $34.7 \mathrm{~mm}$ SL, east of Nakanose, T. Nomura, 28 July 1997; KPM-NI 27124, male, $26.2 \mathrm{~mm}$ SL, male, $36.9 \mathrm{~mm}$ SL, Nakanose, T. Nomura, 24 October 2010. TOKASHIKI-JIMA ISLAND: KPM-NI 22043, female, $35.4 \mathrm{~mm} \mathrm{SL}$, off Tokashiku Beach, H. Gunji, 10 March. 2004; KPM-NI 22057, 
female, $33.6 \mathrm{~mm}$ SL, off Tokashiku Beach, A. Murase, 10 March 2004.

Diagnosis. A species of Helcogramma with the following combination of characters: 13-15 (modally 14) second dorsal-fin spines; $3-4+2+3-4$ mandibular pores; anterior nostril tentacle unbranched; orbital tentacle absent; nape scaled; three longitudinal stripes running from snout to caudal peduncle; row of 6 or 7 spots between middle and ventral stripes.

Distribution. Helcogramma striata is distributed in the Indo-West Pacific, where it ranges from Japan to Australia and from the Andaman Sea to Fiji and the Line Islands (Hansen 1986; Fricke 1997; Holleman 2007). In Japan, this species occurs from Shizuoka Prefecture to the Ryukyu Islands, where it was collected from Take-shima, Iou-jima, Yaku-shima, Nakano-shima, Amami-oshima, Ie-jima, and Tokashiki-jima islands during the present study and had been recorded previously from Nakano-shima (Sakai et al. 2005), Okinawa-jima (Hansen 1986), Miyako-jima (Senou et al. 2007), and Iriomote-jima (Aizawa 1997) islands. It was also confirmed from Yonaguni-jima island (KPM-NR 12127) based on underwater photographs. Helcogramma striata usually inhabits the upper surface of rocks or corals, at depths of 3-20 m.

Remarks. Helcogramma striata is similar to H. maldivensis Fricke and Randall, 1992 in coloration and in lacking both the orbital tentacle and scales on the nape anterior to the dorsal fin. Helcogramma striata can be easily distinguished from $H$. maldivensis by its having usually $14 \mathrm{sec}-$ ond dorsal-fin spines ( $v s$ usually 13 in $H$. maldivensis) and three longitudinal stripes in both sexes ( $v s$ three dotted lines). Mature males of $H$. striata have a dark-reddish body whereas females have a pale red body with a pale yellow area below the lowermost stripe.

\section{Key to the species of Helcogramma in the Ryukyu Islands}

1a Lateral surface of body with three white (dusky in mature males) longitudinal stripes; orbital tentacles absent

H. striata

1b Lateral surface of body without longitudinal stripes; orbital tentacles present .......................................................... 2

2a Symphyseal mandibular pores 5 or more ......................... 3

2b Symphyseal mandibular pore 1...................................... 4

3a Nape without scales; second dorsal-fin spines usually 13.

H. aquila

3b Nape with scales; second dorsal-fin spines usually $15 . .$.

H. inclinata

4a Pored lateral-line scales 28-39; no longitudinal row of reddish or dark blotches on middle of lateral surface of body; largest specimen of more than $50 \mathrm{~mm} \mathrm{SL}$

H. ishigakiensis

$4 \mathrm{~b}$ Pored lateral-line scales 17-25; longitudinal row of reddish or dark blotches in middle of lateral surface of body (indistinct in mature males); largest specimen of less than $35 \mathrm{~mm}$ SL 5a Males with dermal prolongation on tip of snout; second dorsal-fin spines usually 15 ; anterior nostril tentacle unbranched.

H. rhinoceros

5b No dermal prolongation on tip of snout; second dorsalfin spins usually 14; anterior nostril tentacle branched

H. fuscipectoris

\section{Acknowledgments}

We are especially grateful to T. Katano (Okinawa Diving Center) for providing underwater photographs of $H$. ishigakiensis, and to J. Williams (USNM) for providing information on $H$. ishigakiensis and opportunities to examine specimens deposited in his museum. We thank M. Sabaj (ANSP), A. Suzumoto and L. O' Hara (BPBM), H. Yoshigou (HMNH), G. Shinohara and M. Nakae (NSMT), H. Senou (KPM), K. Miyamoto (URM), and K. Hagiwara (YCM) for opportunities to examine specimens. We thank S. N. Chiba and E. Katayama (NSMT) as well as Y. Haraguchi, volunteers, and students of KAUM for their kind assistance with collecting and curating specimens, and G. Yearsley (Ellipsis Editing) for checking an early version of this manuscript. This study was supported in part by Grants-in-Aid for Scientific Research (A: 26241027, B: 24370041 and C: 23580259 and 26450265) from the Japan Society for the Promotion of Science, Tokyo, Japan (JSPS); the JSPS Asian Core Program, "Establishment of Research and Education Network on Coastal Marine Science in Southeast Asia", the JSPS International Training Program "Protect Diversity of Bioresources in the Tropical Area"; the "Coastal Area Capability Enhancement in Southeast Asia Project" of the Research Institute for Humanity and Nature, Kyoto, Japan; and the "Biological Properties of Biodiversity Hotspots in Japan" project of the National Museum of Nature and Science, Tsukuba, Japan.

\section{References}

Aizawa, M. 1997. Tripterygiidae. Pp. 559-560, Okamura, O. and Amaoka, K. (Eds) Sea Fishes of Japan. Yama-kei, Tokyo. [In Japanese]

Aoyagi, H. 1954. Additional notes on the new and the rare fishes of the family Blenniidae from the Riu-Kiu Islands. Dobutsugaku Zasshi 63: 239-242. [In Japanese with English résumé]

Fowler, H. W. 1946. A collection of the fishes obtained in the Riu Kiu Islands by Captain Ernest R. Tinkham, A.U.S. Proceedings of the Academy of Natural Sciences of Philadelphia 98: 123-218.

Fricke, R. 1994. Tripterygiid Fishes of Australia, New Zealand and the Southwest Pacific Ocean (Teleostei). Koeltz Scientific Books, Koenigstein, ix $+585 \mathrm{pp}$.

Fricke, R. 1997. Tripterygiid Fishes of the Western and Central Pacific (Teleostei). Koeltz Scientific Books, Koenigstein, ix +607 pp.

Hansen, P. E. H. 1986. Revision of the tripterygiid fish genus Helcogramma, including descriptions of four new species. Bulletin of Marine Science 38: 313-354.

Hayashi, M. 1993. Tripterygiidae. Pp. 944-948, 1351 In: Nakabo, T. (Ed.). Fishes of Japan with Pictorial Keys to the Species. Tokai University Press, Tokyo. [In Japanese]

Hayashi, M. 2000. Tripterygiidae. Pp. 1077-1086, 1600-1601 In: Naka- 
bo, T. (Ed.). Fishes of Japan with Pictorial Keys to the Species. Second Edition. Tokai University Press, Tokyo. [In Japanese]

Hayashi, M. 2013. Tripterygiidae. Pp. 1280-1290, 2097-2099 In: Nakabo, T. (Ed.). Fishes of Japan with Pictorial Keys to the Species. Third Edition. Tokai University Press, Tokyo. [In Japanese]

Herre, A. W. C. T. 1944. Notes on fishes in the Zoological Museum of Stanford University. XVII. New fishes from Johore and India. Proceedings of the Biological Society of Washington 57: 45-51.

Holleman, W. 1982. Three new species and a new genus of tripterygiid fishes (Blennioidei) from the Indo-West Pacific Ocean. Annals of the Cape Provincial Museums (Natural History) 14 (4): 109-137.

Holleman, W. 2007. Fishes of the genus Helcogramma (Blennioidei: Tripterygiidae) in the Western Indian Ocean, including Sri Lanka, with descriptions of four new species. Smithiana Bulletin 7: 51-81.

Holleman, W. and Bogorodsky, S. V. 2012. A review of the blennioid fish family Tripterygiidae (Perciformes) in the Red Sea, with description of Enneapterygius qirmiz, and reinstatement of Enneapterygius altipinnis Clark, 1980. Zootaxa 3152: 36-60.

Kato, S. 2011. Marine Fishes Illustrated. Seibundo-Shinkosha, Tokyo, 303 pp. [In Japanese]

Klunzinger, C. B. 1871. Synopsis der Fische des Rothen Meeres. Verhandlungen der Kaiserlich-Königlichen Zoologisch-Botanischen Gesellenschaft in Wien 21: 441-668.

Masuda, H., Araga, C. and Yoshino, T. 1975. Coastal Fishes of Southern Japan. Tokai University Press, Tokyo, 379 pp. [In Japanese]

Matsubara, K. 1955. Fish Morphology and Hierarchy. Vol. I. IshizakiShoten, Tokyo, xi+789 pp. [In Japanese]

Motomura, H., Harazaki, S. and Senou, H. 2006. Assessment of standard Japanese names of two triplefins, Helcogramma inclinata and H. nesion (Tripterygiidae), with the northernmost record and newly-recognized diagnostic characters of $H$. inclinata. Japanese Journal of Ichthyology 53 (1): 106-109. [In Japanese]

Motomura, H. and Ishikawa, S. (Eds). 2013. Fish collection building and procedures manual. English edition. The Kagoshima University Museum, Kagoshima and the Research Institute for Humanity and Nature, Kyoto. 70 pp. (Available at http://www.museum. kagoshima-u.ac.jp/staff/motomura/dl_en.html)

Motomura, H., Kuriiwa, K., Katayama, E., Senou, H., Ogihara, G., Meguro, M., Matsunuma, M., Takaya, Y., Yoshida, T., Yamashita, M., Kimura, S., Endo, H., Murase, A., Iwatsuki, Y., Sakurai, Y., Harazaki, S., Hidaka, K., Izumi, H. and Matsuura, K. 2010. Annotated checklist of marine and estuarine fishes of Yaku-shima Island, Kagoshima southern Japan. Pp. 65-247. In: Motomura, H. and Matsuura, K. (Eds), Fishes of Yaku-shima Island-A World Heri- tage Island in the Osumi Group, Kagoshima Prefecture, Southern Japan. National Museum of Nature and Science, Tokyo.

Myers, R. F. and Donaldson, T. J. 2003. The fishes of the Mariana Islands. Micronesica 35-36: 594-648.

Sakai, Y., Kadota, T., Kidera, T., Sagara, K., Shibata, J., Shimizu, N., Takeyama, T., Fujita, O., Hashimoto, H. and Gushima, K. 2005. Fish fauna at reefs of the northern Tokara Islands, southern Japan. Journal of Graduate School of Biosphere Science Hiroshima University 44: 1-14. [In Japanese with English summary]

Senou, H., Kobayashi, Y. and Kobayashi, N. 2007. Coastal Fishes of the Miyako Group, the Ryukyu Islands, Japan. Bulletin of the Kanagawa Prefectural Museum (Natural Science) 36: 47-74.

Senou, H., Kodato, H., Nomura, T. and Yunokawa, K. 2006. Coastal fishes of Ie-jima Island, the Ryukyu Islands, Okinawa, Japan. Bulletin of the Kanagawa Prefectural Museum (Natural Science) 35: 67-92.

Suzuki, T., Senou, H. and Yano, K. 1998. Record of a tripterygiid Helcogramma rhinoceros from Nakano-ugan-jima Island, the Ryukyu Islands, Japan. I. O. P. Diving News 9 (2): 2-4. [In Japanese]

Tashiro, S. 2013. Helcogramma. Pp 294-299. In: Motomura, H., Dewa, S., Furuta, K. and Matsuura, K. (Eds). Fishes of Iou-jima and Takeshima islands, Mishima, Kagoshima, Japan. The Kagoshima University Museum, Kagoshima, and the National Museum of Nature and Science, Tsukuba. 390 pp., 883 figs. [In Japanese]

Tashiro S. and Motomura, H. 2013. First records of the Blacktail Triplefin (Perciformes: Tripterygiidae), Helcogramma aquila, from Japan, with notes on its fresh coloration. Species Diversity 18: 9-14.

Watai, M., Miyazaki, Y., Murase, A. and Senou, H. 2009. Fish fauna of Tokashiku Bay, Tokashiki Island, the Kerama Islands, Okinawa Prefecture. Bulletin of the Kanagawa Prefectural Museum (Natural Science) 38: 119-132. [In Japanese]

Williams, J. T. and Howe, J. C. 2003. Seven new species of the triplefin genus Helcogramma (Tripterygiidae) from the Indo-Pacific. Aqua, Journal of Ichthyology and Aquatic Biology 7: 151-176.

Williams, J. T. and McCormick, C. J. 1990. Two new species of the triplefin fish genus Helcogramma (Tripterygiidae) from the western Pacific Ocean. Copeia 1990: 1020-1030.

Yoshigou, H. and Nakamura, S. 2008. Cataloge [sic] of fish total specimens preserved in Hiwa Museum for Natural History. Material Reports of the Hiwa Museum for Natural History 8: 1-111.

Yoshino, T. 1984. Helcogramma ellioti. P. 281. In: Masuda, H., Amaoka, K., Araga, C., Uyeno, T. and Yoshino, T. (Eds). Fishes of Japanese Archipelago. Tokai University Press, Tokyo. [In Japanese] 